\title{
A Silsesquioxane-Based Diphosphinite Ligand: Synthesis, DFT Study, and Coordination Chemistry
}

\author{
J arl I var van der Vlugt, ${ }^{\dagger}$ Marco Fioroni, ${ }^{\dagger} \mathrm{J}$ ens Ackerstaff, ${ }^{\dagger}$ \\ Rob W. J . M. Hanssen, ${ }^{\dagger}$ Allison M. Mills, ${ }^{\ddagger}$ Anthony L. Spek, ${ }^{\ddagger}$ Auke Meetsma, ${ }^{\S}$ \\ Hendrikus C. L. Abbenhuis, ${ }^{\dagger}$ and Dieter Vogt*,† \\ Schuit Institute of Catalysis, Laboratory of Homogeneous Catalysis, Eindhoven University of \\ Technology, P.O. Box 513, 5600 MB Eindhoven, The Netherlands, Laboratory for Crystal and \\ Structural Chemistry, Department of Chemistry, Utrecht University, Padualaan 8, $3584 \mathrm{CH}$ \\ Utrecht, The Netherlands, and Crystal Structure Center, Chemical Physics, Materials Science \\ Center, University of Groningen, Nijenborgh 4, 9747 AG Groningen, The Netherlands
}

Received J uly 7, 2003

\begin{abstract}
The incompletely condensed silsesquioxane disilanol $\left(\mathrm{c}_{-} \mathrm{C}_{5} \mathrm{H}_{9}\right)_{7} \mathrm{Si}_{7} \mathrm{O}_{9}(\mathrm{OH})_{2} \mathrm{OSiMePh}$ has been used as a backbone for the synthesis of the diphosphiniteligand $\left(\mathrm{c}-\mathrm{C}_{5} \mathrm{H}_{9}\right)_{7} \mathrm{Si}_{7} \mathrm{O}_{9}\left(\mathrm{OPPh}_{2}\right)_{2}-$ $\mathrm{OSiMePh}_{2}(\mathbf{1})$, based on a silsesquioxane framework. By reaction with black selenium, the corresponding selenide (2) was obtained, showing a J se-p value of $815 \mathrm{~Hz}$ in the ${ }^{31} \mathrm{P} \mathrm{NMR}$ spectrum. DFT calculations established a good insight into the electron density of the $\mathrm{P}$ atoms present in the two model compounds $\mathrm{CH}_{3} \mathrm{OPPh}_{2}$ (3) and $\mathrm{Ph}_{2} \mathrm{P}(\mathrm{HSiOH})_{2} \mathrm{OPH}_{2}$ (4). The Mulliken charge distributions show a clear el ectron-withdrawing effect of the siloxy group, which is also present in diphosphinite ligand $\mathbf{1}$. By reaction of compound $\mathbf{1}$ with $\mathrm{PdCl}_{2^{-}}$ $\left(\mathrm{C}_{6} \mathrm{H}_{5} \mathrm{CN}\right)_{2}$, the palladium complex $\left[\mathrm{PdCl}_{2} \mathrm{R}\left(\mathrm{OPPh}_{2}\right)_{2}\right](5)$ was obtained $\left(\mathrm{R}=\left(\mathrm{c}-\mathrm{C}_{5} \mathrm{H}_{9}\right)_{7} \mathrm{Si}_{7} \mathrm{O}_{9}-\right.$ $\mathrm{OSiMePh}$ ). From a similar reaction of $\mathbf{1}$ with $\mathrm{PtCl}_{2}(\mathrm{cod})$, the platinum analogue $\left[\mathrm{PtCl}_{2} \mathrm{R}(\mathrm{OPPh})_{2}\right]$ (6) could be isolated. The equimolar reaction of $\mathrm{Mo}(\mathrm{CO})_{4}(\mathrm{pip})_{2}$ (pip = piperidine) with $\mathbf{1}$ yielded the molybdenum complex $\left[\mathrm{Mo}(\mathrm{CO})_{4} \mathrm{R}\left(\mathrm{OPPh}_{2}\right)_{2}\right](\mathbf{7})$. Ligand $\mathbf{1}$ showed a clear tendency to coordinate in a cis fashion for all complexes 5-7, as was determined by NMR spectroscopy and X-ray crystallography. However, the analogous reaction of $\mathbf{1}$ with $\mathrm{RhCl}(\mathrm{CO})_{2}$ dimer yielded the mononuclear trans-[RhCl(CO)(1)] (8). Complexes 5-8 have been structurally characterized as the first examples of transition-metal complexes with a silsesquioxane-based bidentate phosphinite ligand.
\end{abstract}

\section{Introduction}

Incompletely condensed silsesquioxanes, which only a decade ago were regarded as chemical curiosities, have now been established as versatile, nanostructured building blocks. ${ }^{1,2}$ Ongoing applications involve catalysis and material science where similar parent silanol compounds are involved, as ligands, 3,4 hybrid inorganicorganic materials, ${ }^{5-7}$ or models for silica supports. ${ }^{8} \mathrm{Re}-$ markably, the use of silsesquioxanes as a robust part of dedicated ligands is somewhat undeveloped. For

* To whom correspondence should be addressed. Fax: ++31 (0)40 2455054. Tel: ++31 (0)40 2472483. E-mail: d.vogt@ue.nl.

† Eindhoven University of Technology.

‡ Utrecht University.

$\S$ University of Groningen.

(1) Brown, J . F.; Vogt, L. H. J . Am. Chem. Soc. 1965, 87, 4313.

(2) Feher, F. J .; Terroba, R.; Ziller, J . W. Chem. Commun. 1999, 2309.

(3) (a) Duchateau, R. Chem. Rev. 2002, 102, 3525. (b) Lorenz, V.; Fischer, A.; Giessmann, S.; Gilje, J. W.; Gun'ko, Y.; J acob, K.; Edelmann, F. T. Coord. Chem. Rev. 2000, 206-207, 321.

(4) (a) Hansen, R. W. J. M.; Meetsma, A.; van Santen, R. A.; Abbenhuis, H. C. L. Inorg. Chem. 2001, 40, 4049. (b) Abbenhuis, H. C. L. Chem. Eur. J . 2000, 6, 25.

(5) Maxim, N.; Magusin, P. C. M. M.; Kooyman, P. J .; van Wolput, J . H. M. C.; van Santen, R. A.; Abbenhuis, H. C. L. Chem. Mater. 2001, $13,2958$.

(6) Choi, J .; Harcup, J .; Yee, A. F.; Zhu, Q.; Laine, R. M. J . Am. Chem. Soc. 2001, 123, 11420.

(7) Feher, F. J .; Terroba, R.; J in, R. Z.; Wyndham, K. D.; Lucke, S.; Brutchey, R.; Nguyen, F. Polym. Mater. Sci. Eng. 2000, 82, 301. instance, the synthesis and application of phosphorus ligands based on silsesquioxane frameworks has hardly received attention until now. The few systems reported so far are peripherally functionalized (dendritic) silsesquioxanes containing phosphorus moieties, tethered by various (alkyl) spacers, thus isolating the phosphorus group from the silsesquioxane framework. ${ }^{9-12}$

However, it would be interesting to obtain compounds in which the phosphorus moieties are in closer proximity to the silsesquioxane framework. This could be achieved by reaction of the silanol functionalities with suitable $\mathrm{P}$-containing reagents such as $\mathrm{CIPPh}_{2}$. This approach might also give insight into the electron-withdrawing

(8) (a) Feher, F. J .; Newman, D. A.; Walzer, J . F. J . Am. Chem. Soc. 1989, 111, 1741. (b) Edelmann, F. T. Angew. Chem., Int. Ed. Engl. 1992, 31, 586. (c) Feher, F. J .; Budzichowski, T. A. Polyhedron 1995, 14, 3239. (d) Feher, F. J .; Schwab, J . J .; Philips, S. H.; Eklund, A.; Martinez, E. Organometallics 1995, 14, 4452.

(9) (a) Ropartz, L.; Foster, D. F.; Morris, R. E.; Slawin, A. M. Z.; Cole-Hamilton, D. J. J . Chem. Soc., Dalton Trans. 2002, 1997. (b) Ropartz, L.; Foster, D. F.; Morris, R. E.; Slawin, A. M. Z.; ColeHamilton, D. J . J . Chem. Soc., Dalton Trans. 2002, 361. (c) Ropartz, L.; Foster, D. F.; Morris, R. E.; Cole-Hamilton, D. J.J . Mol. Catal. A: Chem. 2002, 182-183, 99.

(10) Wada, K.; Izuhara, D.; Shiotsuki, M.; Kondo, T.; Mitsudo, T. Chem. Lett. 2001, 31, 734.

(11) Hong, B.; Toms, P. S.; Murfee, H. J .; Lebrun, M. J . Inorg. Chem. 1997, 36, 6146.

(12) (a) Hendan, B. J ; Marsmann, H. C. Appl. Organomet. Chem. 1999, 13, 287. (b) Fei, Z.; Schmutzler, R.; Edelmann, F. T. Z. Anorg. Allg. Chem. 2003, 629, 353. 
character of the silsesquioxane backbone and its influence on the properties of the phosphorus atoms. In considering this topic, we noticed that transition-metal complexes containing silyl-based phosphinite ligands are rare. To date, only four complexes have been structurally characterized, all using the $\mathrm{SiR}^{1} \mathrm{R}^{2}\left(\mathrm{OPP} \mathrm{h}_{2}\right)_{2}$ skeleton with various substituents for $R^{1}$ and $R^{2} \cdot{ }^{13-15}$ We ther efore decided to empl oy silsesqui oxane chemistry for this topic.

Here we report on a silsesquioxane-based bidentate phosphinite ligand, compound $\mathbf{1}$, and its versatile coordination chemistry with palladium, platinum, molybdenum, and rhodium involving square-planar and octahedral geometries.

\section{Results and Discussion}

Preparation of Diphosphinite $\mathbf{1}$. Compound $\mathbf{1}$ is made in a one-step reaction from the incompletely condensed silsesquioxane disilanol $\left(\mathrm{c}_{-} \mathrm{C}_{5} \mathrm{H}_{9}\right)_{7} \mathrm{Si}_{7} \mathrm{O}_{9}(\mathrm{OH})_{2^{-}}$ $\mathrm{OSiMePh}_{2}(\mathbf{A})$, which in turn is available by selective monosilylation of the corresponding trisilanol $\left(\mathrm{c}-\mathrm{C}_{5} \mathrm{H}_{9}\right)_{7-}$ $\mathrm{Si}_{7} \mathrm{O}_{9}(\mathrm{OH})_{3} .16$ The $\mathrm{SiMePh}_{2}$ protecting group is used instead of the more commonly used $\mathrm{SiMe}_{3}$ unit for crystal engineering reasons, as silsesquioxanes containing the former group have a higher tendency to crystallize. ${ }^{17}$ The novel diphosphinite could be obtained in $86 \%$ yield by using $\mathrm{CIPPh}_{2}$ in the presence of triethylamine (eq 1 ). Compound $\mathbf{1}$ was fully characterized by ${ }^{1} \mathrm{H},{ }^{13} \mathrm{C}$,
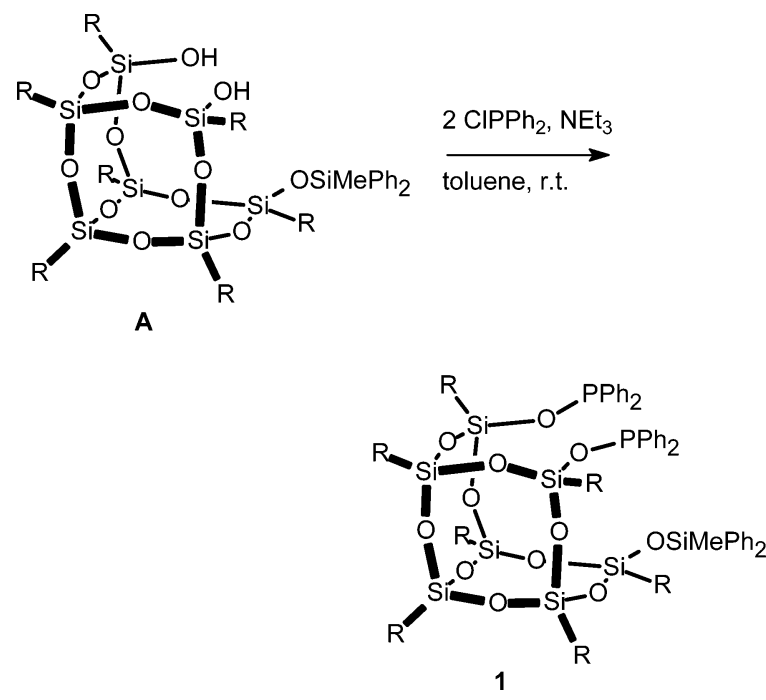

and ${ }^{31 P}$ NMR spectroscopy as well as by elemental analysis.

In the ${ }^{31 P}$ NMR spectrum of compound $\mathbf{1}$, a singlet was present at $\delta 98.7 \mathrm{ppm}$, while the ${ }^{13} \mathrm{C}$ NMR spectrum showed the expected 2:2:1:1:1 ratio for the ipso carbons of the cyclopentyl groups on the silicon atoms in the silsesquioxane framework. To get an impression of the electronic properties of the diphosphinite ligand, a

(13) Hogg, J . K.; J ames, S. L.; Orpen, A. G.; Pringle, P. G. J . Organomet. Chem. 1994, 480, c1.

(14) Gray, G. M.; Fish, F. P.; Srivastava, D. K.; Varshney, A.; van der Woerd, M. J .; Ealick, S. E. J . Organomet. Chem. 1990, 385, 49.

(15) Voelker, H.; Freitag, S.; Pieper, U.; Roesky, H. W. Z. Anorg.

Allg. Chem. 1995, 621, 694

(16) Feher, F.J .; Budzichowski, T. A.; Blanski, R. L.; Weller, K.J .; Ziller, J. W. Organometallics 1991, 10, 2526.

(17) Sworonska-Ptasinska, M. D.; Duchateau, R.; van Santen, R. A Yap, G. P. A. Organometallics 2001, 20, 3519.<smiles>COP(c1ccccc1)c1ccccc1</smiles><smiles>O[SiH](OPc1ccccc1)O[Si](O)(O)OPP</smiles>

3

4

Figure 1. Illustration of the two structures used in the DFT calculations to compare the electron-withdrawing character of $\mathbf{1}$ with that of an ordinary diarylphosphinite.

Table 1. Selected Bond Lengths and Angles for the Optimized Geometries of Model Compounds 3 and 4

\begin{tabular}{|c|c|c|c|}
\hline \multicolumn{2}{|c|}{$\mathrm{CH}_{3} \mathrm{OPPh}_{2}(3)$} & \multicolumn{2}{|c|}{$\mathrm{H}_{2} \mathrm{P}(\mathrm{O}(\mathrm{HSiOH}))_{2} \mathrm{OPPh}_{2}(\mathbf{4})$} \\
\hline \multicolumn{4}{|c|}{ Bond Lengths $(\AA)$} \\
\hline $\begin{array}{l}\mathrm{P}-\mathrm{C}_{\alpha, P h} \\
\mathrm{P}-\mathrm{O} \\
\mathrm{C}-\mathrm{O} \\
\mathrm{C}-\mathrm{H}\end{array}$ & $\begin{array}{l}1.85 \\
1.68 \\
1.43 \\
1.09\end{array}$ & $\begin{array}{l}\mathrm{P}-\mathrm{C}_{\alpha, \mathrm{Ph}} \\
\mathrm{P} \mathrm{Ph}-\mathrm{O} \\
\mathrm{Si}-\mathrm{O} \\
\mathrm{P}_{\mathrm{H}}-\mathrm{O} \\
\mathrm{P}-\mathrm{H} \\
\mathrm{Si}-\mathrm{H}\end{array}$ & $\begin{array}{l}1.84 \\
1.68 \\
1.66 \\
1.62 \\
1.42 \\
1.46\end{array}$ \\
\hline \multicolumn{4}{|c|}{ Bond Angles (deg) } \\
\hline $\begin{array}{l}\mathrm{C}_{\alpha, \mathrm{Ph}}-\mathrm{P}-\mathrm{O} \\
\mathrm{P}-\mathrm{O}-\mathrm{CH}_{3}\end{array}$ & $\begin{array}{l}99.19 \\
117.28\end{array}$ & $\begin{array}{l}\mathrm{C}_{\alpha, \mathrm{Ph}}-\mathrm{P}-\mathrm{O} \\
\mathrm{P} \mathrm{Ph}-\mathrm{O}-\mathrm{Si} \\
\mathrm{Si}-\mathrm{O}-\mathrm{Si} \\
\mathrm{Si}-\mathrm{O}-\mathrm{P}_{\mathrm{H}} \\
\mathrm{O}-\mathrm{P}-\mathrm{H}\end{array}$ & $\begin{array}{l}98.17 \\
127.73 \\
168.50 \\
128.29 \\
97.65\end{array}$ \\
\hline
\end{tabular}

reaction with elemental selenium was carried out, to convert both phosphinite groups into the corresponding selenides. Since the stability toward oxidation is fairly low for most phosphinites, the reaction went to completion in approximately $1 \mathrm{~h}$ in toluene at $100{ }^{\circ} \mathrm{C}$. In the 31P NMR spectrum of diselenide 2 , in $\mathrm{CH}_{2} \mathrm{Cl}_{2}$, a singlet was found at $\delta 69.8 \mathrm{ppm}$ together with two ${ }^{77} \mathrm{Se}$ satellites and a corresponding coupling constant J se-p of $815 \mathrm{~Hz}$. This value is in agreement with the few available literature data. ${ }^{18-20}$

DFT Calculations on Model Compounds. (a) Models. Silsesquioxanes are reported to have el ectronwithdrawing character. ${ }^{21}$ To compare the electronic properties of the silyl-based phosphinite ligand $\mathbf{1}$ with those of a "normal" al koxy-based phosphinite, the electron density on the $P$ atoms of two respective model compounds was calculated using DFT methods. As simple model precursors, $\mathrm{CH}_{3} \mathrm{OPPh}_{2}(3)$ and $\mathrm{H}_{2} \mathrm{P}(\mathrm{O}(\mathrm{HSiOH}))_{2-}$ $\mathrm{OPPh}_{2}(4)$ have been considered (Figure 1). The silyl chain is long enough to avoid el ectronic influence from the opposite end side of the mol ecule and, at the same time, provides information on the differences between the $\mathrm{PH}_{2}$ group, commonly used in modeling phosphorus moieties, and the more realistic $\mathrm{PPh}_{2}$ group. The $\mathrm{PH}_{2}$ unit is normally chosen for obvious restrictions on the computational capabilities.

(b) Geometries. From the calculations run on the model compounds as depicted in Figure 1, the optimized geometries gave the selected geometric parameters (bond lengths and angles) listed in Table 1. From the bond lengths in Table 1 it is clear that there is a slight

(18) Balakrishna, M. S.; Panda, R.; Mague, J . T. Dalton 2002, 4617

(19) Suárez, A.; Méndez-Rojas, M. A.; Pizzano, A. Organometallics 2002, 21, 4611. 51.

(20) Allen, D. W.; Taylor, B. F. J . Chem. Soc., Dalton Trans. 1982

(21) Feher, F. J .; Walzer, J . F.; Blanski, R. L. J . Am. Chem. Soc 1991, 113, 3618 
Table 2. Selected Mulliken Atomic Charges ${ }^{\mathrm{a}}$ for Model Compounds 3 and 4

\begin{tabular}{lrlrr}
\hline \multicolumn{2}{c}{$\mathrm{CH}_{3} \mathrm{OPPh}_{2}$ (3) } & & \multicolumn{2}{c}{$\mathrm{H}_{2} \mathrm{P}(\mathrm{O}(\mathrm{HSiOH}))_{2} \mathrm{OPPh}_{2}(\mathbf{4})^{\mathrm{b}}$} \\
\cline { 1 - 2 } $\mathrm{P}$ & 0.192 & & $\mathrm{PPh}_{2}$ & 0.260 \\
$\mathrm{O}$ & -0.516 & & $\mathrm{Ph}_{2} \mathrm{PO}$ & -0.580 \\
$\mathrm{CH}_{3}$ & -0.238 & & $\mathrm{Si}$ & 1.050 \\
& & $\mathrm{OPH}_{2}$ & -0.689 \\
& & $\mathrm{PH}_{2}$ & 0.389
\end{tabular}

a Electron units (charge of electron is equal to -1 ). ${ }^{\mathrm{b}}$ Atoms considered in the Mulliken population analysis are given in italics.

difference in the $\mathrm{P}-\mathrm{C}_{\alpha, \mathrm{Ph}}$ length found for the two compounds of $0.1 \AA\left(\mathrm{C}_{\alpha, \mathrm{Ph}}\right.$ is the ipso carbon of the phenyl group attached to phosphorus). This difference can beconsidered within the error limit of the calculated quantities. The $\mathrm{P}-\mathrm{O}$ bond lengths are the same. A sensible difference, as expected, has been found between the $\mathrm{P}-\mathrm{O}$ bond length of the $\mathrm{H}_{2} \mathrm{P}(\mathrm{O}(\mathrm{HSiOH}))_{2} \mathrm{OPPh}_{2}$ molecule when $\mathrm{P}$ is attached to a phenyl group (0.184 $\mathrm{nm}$ ) or to a hydrogen atom $(0.162 \mathrm{~nm})$.

The only comparable angles between the two molecules, the $\mathrm{C}_{\alpha, \mathrm{Ph}}-\mathrm{P}-\mathrm{O}$ angles, are shown to yield a difference of $\sim 1^{\circ}$, with that of $\mathrm{CH}_{3} \mathrm{OPPh}$ being higher in value. From the preceding geometrical analysis, little can be deduced on the difference between the $\mathrm{PPh}_{2}$ moieties present in the silyl-based model compound $\mathbf{4}$ and in the $\mathrm{CH}_{3} \mathrm{OPPh}$ reference system 3 . The following charge distribution could give a better estimation of the difference between the $P$ atoms in the two model compounds.

(c) Charges. The electronic distributions in the modeled compounds were analyzed through an electrostatic charge analysis. Although atomic charges are not an observable in quantum mechanics, they are appropriate to get an idea of the electronic distribution. Different schemes and algorithms can be employed. In this study the Mulliken population analysis was considered. ${ }^{22}$ This method assigns charges by partitioning the orbital overlap evenly between the two atoms which are involved. In Table 2 the Mulliken atomic charges between the two compounds $\mathbf{3}$ and $\mathbf{4}$ are reported and compared.

A slight difference between the charge on the phosphorus atom of $\mathbf{3}$ and the $\mathrm{PPh}_{2}$ atom of $\mathbf{4}$ is calculated $(|0.068|)$ due to the higher electron withdrawing effect of the sil oxy skel eton. This rel ates to the charges found for the oxygen atoms, since a higher negative charge (|0.064|) is present in 4 . Also, the positive charge present on the silicon atom of the silyl-based model compound supports this, compared to the negative charge situated on the carbon of the methoxy group in compound 3. The two central silicon atoms of the $\mathrm{H}_{2} \mathrm{P}(\mathrm{O}(\mathrm{HSiOH}))_{2} \mathrm{OPPh}_{2}$ model show the same charges, while the oxygens attached to the two phosphorus atoms have a charge difference of $|0.109|$. Of note is the difference between the two phosphorus atoms in compound 4, in the $\mathrm{PPh}_{2}$ group and the $\mathrm{PH}_{2}$ group, reaching a value of $|0.129|$, which makes evident the large difference between the two systems. In the limit of the Mulliken analysis and of the model compounds here considered, the charge distributions showed a clear difference between the two systems: i.e., whether the $\mathrm{P}$ atom is fol lowed by an alkoxy or a siloxy chain. This may serve as an approxima-

(22) Mulliken, R. S. J . Chem. Phys. 1955, 23, 1833. tion for the electron-withdrawing character expected for silsesquioxane frameworks such as those present in compound $\mathbf{1}$ and as such indicates that silsesquioxanes can be regarded as models for silica surfaces. 8,21

To show the applicability of $\mathbf{1}$ as a new silyl-based diphosphinite ligand for the preparation of such metal complexes, we decided to study its coordination behavior toward platinum, palladium, molybdenum, and rhodium precursors.

Preparation of Dichloropalladium(II) Complex 5. Reaction of $\mathrm{PdCl}_{2}\left(\mathrm{C}_{6} \mathrm{H}_{5} \mathrm{CN}\right)_{2}$ with $\mathbf{1}$ for $2 \mathrm{~h}$ at room temperature resulted in the yellow solid compound $\left[\mathrm{PdCl}_{2}\left\{\left(\mathrm{C}-\mathrm{C}_{5} \mathrm{H}_{9}\right)_{7} \mathrm{Si}_{7} \mathrm{O}_{9}\left(\mathrm{OPPh}_{2}\right)_{2} \mathrm{OSiMePh}_{2}\right\}\right]$ (eq 2), for which the ${ }^{31}$ P NMR spectrum showed a singlet at $\delta 91.8$ ppm.
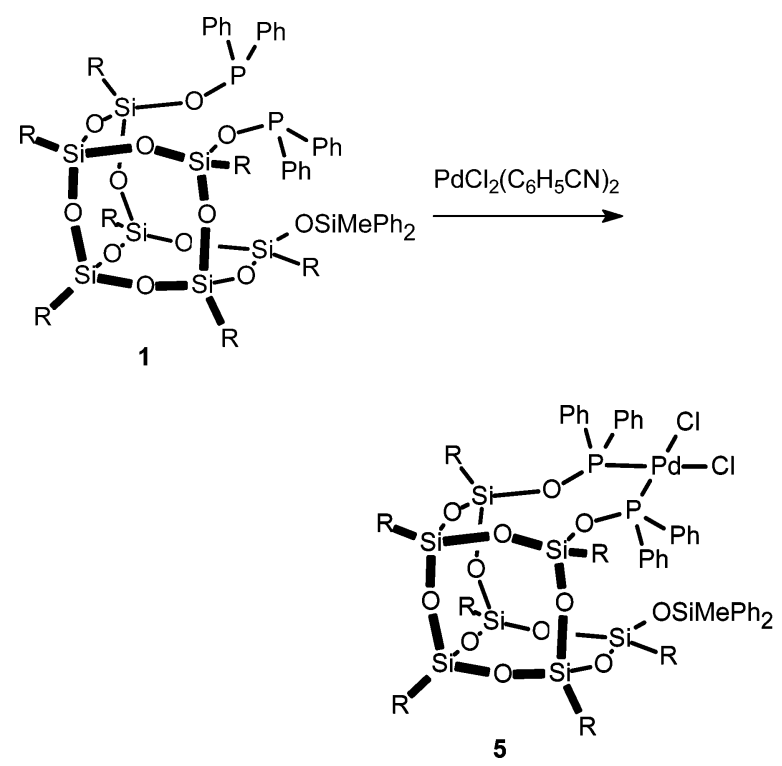

The ${ }^{13} \mathrm{C}$ NMR spectrum showed a peak ratio pattern of 2:1:1:2:1 for the ipso carbons of the cyclopentyl groups. This indicates that the original silsesquioxane framework is still intact. Single crystals, suitable for analysis by X-ray diffraction, were obtained by layering a dichloromethane solution of $\mathrm{PdCl}_{2}(\mathbf{1})$ with acetonitrile. The molecular structure is depicted in Figure 2. Selected bond lengths and angles can be found in Table 3 . Clearly, diphosphinite $\mathbf{1}$ has coordinated as a bidentate ligand, adopting a cis conformation to the palladium atom. The complex cis-[ $\left[\mathrm{PdCl}_{2}(\mathbf{1})\right](\mathbf{5})$ crystal lized in the triclinic space group $P \overline{1}$. This structure represents the first palladium-silyl phosphinite complex to be structurally characterized.

The geometry around the palladium atom in complex $\mathbf{5}$ is slightly distorted square planar. This is evident from the bite angle $\mathrm{P}_{1}-\mathrm{Pd}-\mathrm{P}_{2}$ of $92.35(3)^{\circ}$, while the $\mathrm{Cl}_{1}-\mathrm{Pd}-\mathrm{Cl}_{2}$ angle is $89.71(3)^{\circ}$. The $\mathrm{P}_{1}-\mathrm{Pd}-\mathrm{Cl}_{2}$ angle is only $168.86(3)^{\circ}$, similar to the $\mathrm{P}_{2}-\mathrm{Pd}-\mathrm{Cl}_{1}$ angle of $168.44(3)^{\circ}$. As viewed al ong the $\mathrm{Pd}-\mathrm{P}$ bond, the total sums of the angles around the phosphorus atoms are $345.51^{\circ}\left(\mathrm{P}_{1}\right)$ and $343.16^{\circ}\left(\mathrm{P}_{2}\right)$. Four of the cyclopentyl rings as well as one phenyl ring of the $\mathrm{SiMePh}_{2}$ moiety are disordered over two conformations of equal distribution. The intramolecular P-P distance is 3.2500(13) $\AA$. The bond lengths between palladium and phosphorus $\mathrm{Pd}_{1}-\mathrm{P}_{1}$ and $\mathrm{Pd}_{1}-\mathrm{P}_{2}$ are 2.2497(9) and 2.2550(10) $\AA$, respectively. These bond lengths fall within the expected 


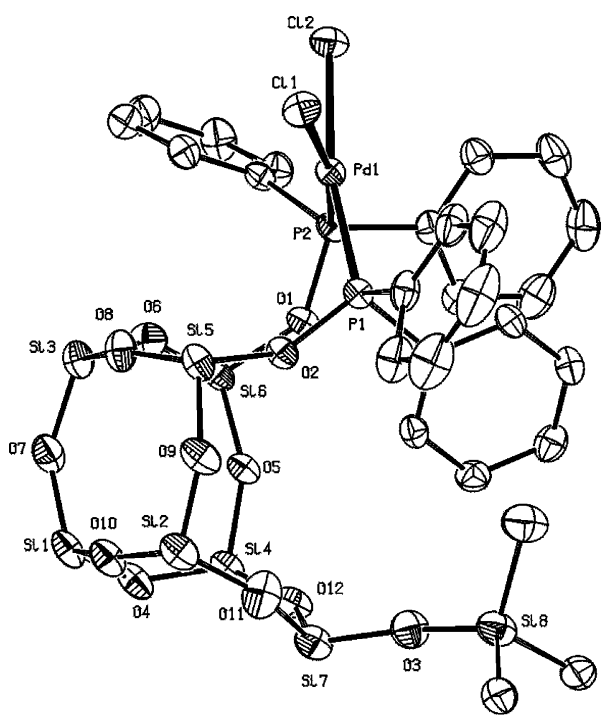

Figure 2. ORTEP representation of complex $\mathbf{5}$, cis-[ $\left[\mathrm{PdCl}_{2-}\right.$ (1)]. Displacement ellipsoids are drawn at the 50\% probability level. All hydrogen atoms and the cyclopentyl side groups are omitted for clarity.

Table 3. Selected Bond Lengths and Angles for Complex 5, cis-[PdCl $2(1)]$

\begin{tabular}{llll}
\hline \multicolumn{5}{c}{ Bond Lengths $(\AA)$} \\
$\mathrm{Pd}-\mathrm{P}_{1}$ & $2.2497(9)$ & $\mathrm{Si}_{6}-\mathrm{O}_{1}$ & $1.660(2)$ \\
$\mathrm{Pd}-\mathrm{Cl}_{2}$ & $2.3591(10)$ & $\mathrm{Si}_{7}-\mathrm{O}_{3}$ & $1.611(3)$ \\
$\mathrm{Si}_{5}-\mathrm{O}_{2}$ & $1.672(3)$ & $\mathrm{Pd}-\mathrm{Cl}_{1}$ & $2.3589(10)$ \\
$\mathrm{Si}_{5}-\mathrm{O}_{9}$ & $1.622(3)$ & $\mathrm{P}_{2}-\mathrm{O}_{1}$ & $1.601(2)$ \\
$\mathrm{P}_{1}-\mathrm{P}_{2}$ & $3.2500(13)$ & $\mathrm{Si}_{4}-\mathrm{O}_{9}$ & $1.620(3)$ \\
$\mathrm{Pd}-\mathrm{P}_{2}$ & $2.2550(10)$ & $\mathrm{Si}_{8}-\mathrm{O}_{3}$ & $1.636(3)$ \\
$\mathrm{P}_{1}-\mathrm{O}_{2}$ & $1.584(2)$ \\
\multicolumn{5}{c}{} \\
$\mathrm{Cl}_{1}-\mathrm{Pd}-\mathrm{Cl}_{2}$ & \multicolumn{5}{c}{ Bond Angles (deg) } \\
$\mathrm{Cl}_{2}-\mathrm{Pd}-\mathrm{P}_{2}$ & $87.57(3)$ & $\mathrm{Si}_{6}-\mathrm{O}_{1}-\mathrm{P}_{2}$ & $139.20(15)$ \\
$\mathrm{Si}_{5}-\mathrm{O}_{2}-\mathrm{P}_{1}$ & $139.12(16)$ & $\mathrm{Si}_{4}-\mathrm{O}_{9}-\mathrm{Si}_{5}$ & $147.52(17)$ \\
$\mathrm{Pd}-\mathrm{P}_{2}-\mathrm{O}_{1}$ & $115.92(9)$ & $\mathrm{Cl}_{2}-\mathrm{Pd}_{2}-\mathrm{P}_{1}$ & $92.47(3)$ \\
$\mathrm{P}_{1}-\mathrm{Pd}-\mathrm{P}_{2}$ & $92.35(3)$ & $\mathrm{Pd}_{1}-\mathrm{P}_{1}-\mathrm{O}_{2}$ & $168.44(3)$ \\
$\mathrm{P}_{1}-\mathrm{Pd}-\mathrm{Cl}_{2}$ & $168.86(3)$ & $\mathrm{Si}_{7}-\mathrm{O}_{3}-\mathrm{Si}_{8}$ & $114.96(9)$ \\
\multicolumn{5}{c}{$158.93(19)$}
\end{tabular}

range, compared to those of other $\left[\mathrm{PdCl}_{2}(\mathrm{P})_{2}\right]$ complexes described in the literature. ${ }^{23-25}$ The trans- $\left[\mathrm{PdCl}_{2}(\mathrm{P})_{2}\right]$ complex ( $\mathrm{P}$ is a calix[4]arene-derived monophosphinite) of $F$ aidherbe et al. showed the largest deviation, with a $\mathrm{Pd}-\mathrm{P}$ bond length of 2.3251(6) A. ${ }^{26}$ Furthermore, the palladium-chloride bond distances $\mathrm{Pd}_{1}-\mathrm{Cl}_{1}$ (2.3589(10) $\AA)$ and $\mathrm{Pd}_{1}-\mathrm{Cl}_{2}(2.3591(10) \AA$ ) are in their normal ranges. ${ }^{23-26}$ The silyl ether bonds $\mathrm{Si}_{5}-\mathrm{O}_{2}$ and $\mathrm{Si}_{6}-\mathrm{O}_{1}$ are long at $1.672(3)$ and $1.660(2) \AA$, compared to the average $\mathrm{Si}-\mathrm{O}$ bond lengths of the silsesquioxane framework (average $1.62 \AA$ ), indicative of a lower electron density in the former bonds. $\mathrm{The} \mathrm{Si}_{8}-\mathrm{O}_{3}$ bond length is 1.636(3) $\AA$, similar to those for other SiM ePh 2 -containing structures reported by Duchateau ${ }^{27}$ and slightly longer compared to values found with $\mathrm{SiMe}_{3}$ as the substituent. ${ }^{28}$ Other silyl-oxygen bond lengths and $\mathrm{Si}-\mathrm{O}-\mathrm{Si}$ angles are normal, within the wide range

(23) Berdagué, P.; Courtieu, J .; Adams, H.; Bailey, N. A.; Maitlis, P. M. J . Chem. Soc., Chem. Commun. 1994, 1589.

(24) Evans, D. R.; Huang, M.; Fettinger, J . C.; Williams, T. L. Inorg. Chem. 2002, 41, 5986.

(25) Stolmar, M.; Floriani, C.; Chiesi-Villa, A.; Rizzoli, C. Inorg. Chem. 1997, 36, 1694.

(26) Faidherbe, P.; Wieser, C.; Matt, D.; Harriman, A.; De Cian, A.; Fischer, J. Eur. J . Inorg. Chem. 1998, 451.

(27) Gerritsen, G.; Duchateau, R.; van Santen, R. A.; Yap, G. P. A Organometallics 2003, 22, 100. known for silsesquioxane complexes. There is a significant tetrahedral distortion in the coordination plane around the palladium atom, illustrated by the calculated dihedral angle between the $\mathrm{P}_{1}-\mathrm{Pd}-\mathrm{P}_{2}$ plane and the $\mathrm{Cl}_{1}-\mathrm{Pd}-\mathrm{Cl}_{2}$ plane of $18^{\circ}$. The $\mathrm{P}-\mathrm{O}$ bond lengths of 1.584(2) $\AA\left(\mathrm{P}_{1}-\mathrm{O}_{2}\right)$ and 1.601(2) $\AA\left(\mathrm{P}_{2}-\mathrm{O}_{1}\right)$ are found to be smaller than the values normally reported in the literature for phosphinites coordinated to palladium. ${ }^{23-26,29}$ This is another indication that the silsesquioxane framework indeed possesses electron-withdrawing character.

Preparation of Dichloroplatinum(II) Complex 6. To establish if the structural motif found for complex $\mathbf{5}$ also occurs in complexes with other metals of the same group, we decided to investigate the analogous platinum complex. Reaction of $\mathrm{PtCl}_{2}$ (cod) as the metal source with ligand $\mathbf{1}$ yielded the straightforward formation of the white solid compound $\left[\mathrm{PtCl}_{2}\left\{\left(\mathrm{C}-\mathrm{C}_{5} \mathrm{H}_{9}\right)_{7} \mathrm{Si}_{7} \mathrm{O}_{9}\left(\mathrm{OPPh}_{2}\right)_{2^{-}}\right.\right.$

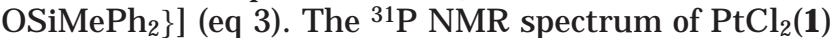

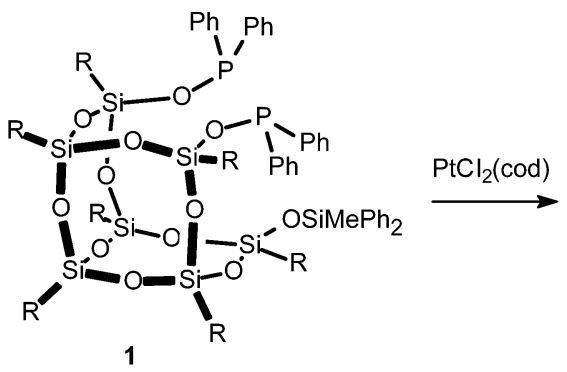

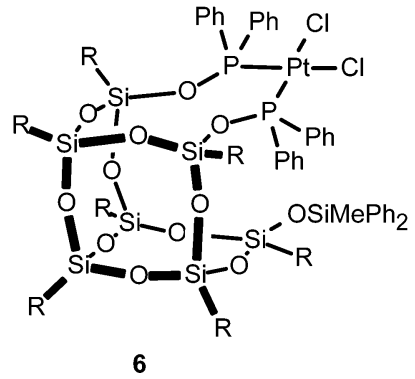

shows a single peak at $\delta 64.5 \mathrm{ppm}$, flanked by ${ }^{195} \mathrm{pt}$ satel lites and a coupling constant J pt-p of $4246 \mathrm{~Hz}$. This value is a clear indication of the cis coordination of the diphosphinite to the platinum center. ${ }^{18,25,30-32}$ The chemical shift difference with the uncoordinated ligand $\Delta \delta$ is $34.2 \mathrm{ppm}$ upfield in the ${ }^{31} \mathrm{P}$ NMR spectrum, considerably more than that found from the reaction to yield complex 5, where $\Delta \delta$ is only $5.9 \mathrm{ppm}$ upfield. In the ${ }^{13} \mathrm{C}$ NMR spectrum, the characteristic signals for the ipso carbons of the cyclopentyl side groups appeared in the normal region, in a 1:1:1:2:2 ratio. This indicates that the silsequioxane framework remained intact during the complexation.

In addition, single crystals could be obtained by slow diffusion of acetonitrile into a $\mathrm{CH}_{2} \mathrm{Cl}_{2}$ solution of $\mathrm{PtCl}_{2-}$

(28) Abbenhuis, H. C. L.; Burrows, A. D.; Kooijman, H.; Lutz, M.; Palmer, M. T.; van Santen, R. A.; Spek, A. L. Chem. Commun. 1998, 2627.

(29) Nishimata, T.; Yamaguchi, K.; Mori, M. Tetrahedron Lett. 1999, 40,5713 .

(30) Arena, C. G.; Drommi, D.; Faraone, F.; Graiff, C.; Tiripicchio, A. Eur. J . Inorg. Chem. 2001, 247.

(31) Csók, Z.; Szalontai, G.; Czira, G.; Kollár, L. J . Organomet. Chem. 1998, 570, 23.

(32) Xu, W.; Rourke, J . P.; Vittal, J . J .; Puddephatt, R. J . Inorg. Chem. 1995, 34, 323. 


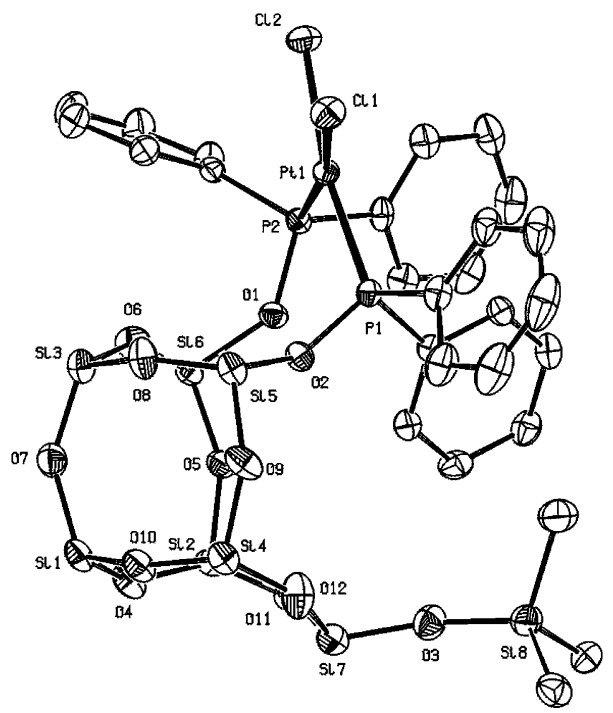

Figure 3. ORTEP representation of complex $\mathbf{6}$, cis- $\left[\mathrm{PtCl}_{2-}\right.$ (1)]. Displacement ellipsoids are drawn at the 50\% probability level. All hydrogen atoms and the cyclopentyl side groups are omitted for clarity.

Table 4. Selected Bond Lengths and Angles for Complex 6, cis-[PtCl $\left.\mathrm{P}_{2}(1)\right]$

\begin{tabular}{llcc}
\hline \multicolumn{5}{c}{ Bond Lengths $(\AA)$} \\
$\mathrm{Pt}-\mathrm{P}_{1}$ & $2.2290(7)$ & $\mathrm{Si}_{6}-\mathrm{O}_{1}$ & $1.662(2)$ \\
$\mathrm{Pt}-\mathrm{Cl}_{2}$ & $2.3621(8)$ & $\mathrm{Si}_{7}-\mathrm{O}_{3}$ & $1.614(2)$ \\
$\mathrm{Si}_{5}-\mathrm{O}_{2}$ & $1.666(2)$ & $\mathrm{Pt}_{-} \mathrm{Cl}_{1}$ & $2.3640(8)$ \\
$\mathrm{Si}_{5}-\mathrm{O}_{9}$ & $1.618(2)$ & $\mathrm{P}_{2}-\mathrm{O}_{1}$ & $1.603(2)$ \\
$\mathrm{P}_{1}-\mathrm{P}_{2}$ & $3.2341(10)$ & $\mathrm{Si}_{4}-\mathrm{O}_{9}$ & $1.623(2)$ \\
$\mathrm{Pt}-\mathrm{P}_{2}$ & $2.2372(8)$ & $\mathrm{Si}_{8}-\mathrm{O}_{3}$ & $1.633(2)$ \\
$\mathrm{P}_{1}-\mathrm{O}_{2}$ & $1.591(2)$ & & \\
\multicolumn{5}{c}{} \\
$\mathrm{Cl}_{1}-\mathrm{Pt}-\mathrm{Cl}_{2}$ & $87.34(3)$ & $\mathrm{Si}_{6}-\mathrm{O}_{1}-\mathrm{P}_{2}$ & $138.94(14)$ \\
$\mathrm{Cl}_{2}-\mathrm{Pt}-\mathrm{P}_{2}$ & $88.28(3)$ & $\mathrm{Si}_{4}-\mathrm{O}_{9}-\mathrm{Si}_{5}$ & $147.38(16)$ \\
$\mathrm{Si}_{5}-\mathrm{O}_{2}-\mathrm{P}_{1}$ & $137.62(14)$ & $\mathrm{Cl}_{1}-\mathrm{Pt}_{-}-\mathrm{P}_{1}$ & $93.25(3)$ \\
$\mathrm{Pt}_{-} \mathrm{P}_{2}-\mathrm{O}_{1}$ & $115.48(9)$ & $\mathrm{P}_{2}-\mathrm{Pt}_{1}-\mathrm{Cl}_{1}$ & $168.85(3)$ \\
$\mathrm{P}_{1}-\mathrm{Pt}-\mathrm{P}_{2}$ & $92.80(3)$ & $\mathrm{Pt}_{2}-\mathrm{P}_{1}-\mathrm{O}_{2}$ & $115.84(8)$ \\
$\mathrm{P}_{1}-\mathrm{Pt}-\mathrm{Cl}_{2}$ & $170.31(3)$ & $\mathrm{Si}_{7}-\mathrm{O}_{3}-\mathrm{Si}_{8}$ & $161.04(17)$
\end{tabular}

(1). A crystallographic study confirmed the structure of cis- $\left[\mathrm{PtCl}_{2}(\mathbf{1})\right](\mathbf{6})$ to be al most isomorphous with that of complex 5. The molecular structure for complex $\mathbf{6}$ is shown in Figure 3. Selected bond lengths and angles can be found in Table 4.

The geometry around the platinum atom in complex 6 is distorted square planar. The bite angle for the diphosphiniteligand, $\mathrm{P}_{1}-\mathrm{Pt}-\mathrm{P}_{2}$, is $92.80(3)^{\circ}$, while the $\mathrm{Cl}_{1}-\mathrm{Pt}-\mathrm{Cl}_{2}$ angle turned out to be $87.34(3)^{\circ}$. Similar values are found for $\mathrm{P}_{1}-\mathrm{Pt}-\mathrm{Cl}_{1}\left(93.25(3)^{\circ}\right)$ and $\mathrm{P}_{2}-\mathrm{Pt}-\mathrm{Cl}_{2}\left(88.28(3)^{\circ}\right)$. The trans $\mathrm{P}-\mathrm{Pt}-\mathrm{Cl}$ angles are only $168.85(3)$ and $170.31(3)^{\circ}$, respectively. Four of the cyclopentyl rings as well as one phenyl ring of the $\mathrm{SiM} \mathrm{ePh}_{2}$ moiety are disordered over two conformations of equal distribution. The intramolecular $\mathrm{P}-\mathrm{P}$ distance is $3.2341(10) \AA$, marginally smaller than the distance found in complex $\mathbf{5}$. The total sums of the angles around the phosphorus atoms, viewed along the $\mathrm{Pt}-\mathrm{P}$ bonds, are $346.35^{\circ}\left(\mathrm{P}_{1}\right)$ and $343.64^{\circ}\left(\mathrm{P}_{2}\right)$. The $\mathrm{Pt}-\mathrm{P}$ bond lengths (2.2290(7) $\AA$ for $\mathrm{Pt}-\mathrm{P}_{1}$ and 2.2372(8) $\AA$ for $\mathrm{Pt}-\mathrm{P}_{2}$ ) and the $\mathrm{Pt}-\mathrm{Cl}$ bond lengths (2.3640(8) $\AA$ for $\mathrm{Pt}-\mathrm{Cl}_{1}$ and 2.3621 (8) $\AA$ for $\mathrm{Pt}-\mathrm{Cl}_{2}$ ) are in their expected ranges, respectively, as reported for other platinum-phosphinite complexes. ${ }^{13,18,25,26,30,33}$ In the platinum-(silyl-diphosphinite) compound cis-[ $\mathrm{PtCl}_{2-}$ $\left.\mathrm{SiPh}_{2}\left(\mathrm{OPPh}_{2}\right)_{2}\right](\mathbf{B})$, described by the group of Pringle,

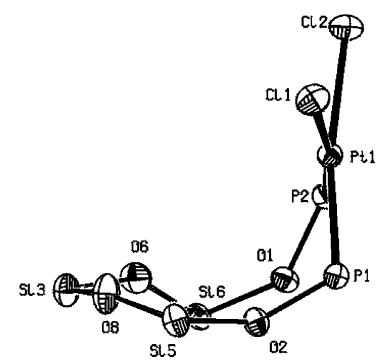

Figure 4. Ten-membered chelate ring of complex 6, showing the tetrahedral distortion around the squareplanar platinum atom and the conformation of the chelating silsesquioxane diphosphinite ring.

the $\mathrm{P}-\mathrm{O}$ and $\mathrm{Si}-\mathrm{O}$ bond lengths are 1.637 and $1.691 \AA$ on average, respectively. ${ }^{13}$ In complex 6 , the $\mathrm{P}-\mathrm{O}$ bond lengths are considerably shorter at $1.591(2) \AA\left(\mathrm{P}_{1}-\mathrm{O}_{2}\right)$ and $1.603(2) \AA\left(\mathrm{P}_{2}-\mathrm{O}_{1}\right)$. The average $\mathrm{Si}-\mathrm{O}$ bond length found in $\mathbf{B}$ is significantly longer than the values found for $\mathrm{Si}_{5}-\mathrm{O}_{2}(1.666(2) \AA)$ and $\mathrm{Si}_{6}-\mathrm{O}_{1}(1.662(2) \AA)$ in complex 6. However, comparison of these silicon atoms is hampered by their different respective substitution patterns. With regard to the different $\mathrm{Si}-\mathrm{O}$ bonds present in complex $\mathbf{6}$, similar considerations can be made as for complex 5 . The bonds $\mathrm{Si}_{5}-\mathrm{O}_{2}$ and $\mathrm{Si}_{6}-\mathrm{O}_{1}$ are considerably longer than those of the silsesquioxane framework, such as $\mathrm{Si}_{5}-\mathrm{O}_{9}(1.618(2) \AA)$ and $\mathrm{Si}_{7}-\mathrm{O}_{3}$

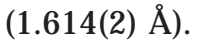

The 10-membered chelate ring, depicted in Figure 4, present in complex $\mathbf{6}$ resembles the structure reported by Balakrishna et al. for a $\mathrm{PtCl}_{2}(\mathrm{PP})$ complex, bearing a diphosphinite ligand PP derived from bis(2-hydroxy1-naphthyl)methane. ${ }^{18}$ In the molecular structure for this specific compound, the metal atom is pointing upward with respect to the remaining atoms of the chelate ring. The strong disposition of the platinum coordination plane from the silesquioxane chelate ring in complex $\mathbf{6}$ is evident from the dihedral angle between the $\mathrm{P}_{1}-\mathrm{Pt}-\mathrm{P}_{2}$ plane and the $\mathrm{O}_{1}-\mathrm{O}_{2}-\mathrm{Si}_{5}$ plane of $61.1^{\circ}$. The dihedral angle between the $\mathrm{P}_{1}-\mathrm{Pt}-\mathrm{P}_{2}$ plane and the $\mathrm{O}_{1}-\mathrm{O}_{2}-\mathrm{Si}_{6}$ plane is even larger at $90.0^{\circ}$. In complex 6, a similar, slightly smaller, tetrahedral distortion from the ideal plane is evident, as found in complex $\mathbf{5}$. The angle between the $\mathrm{P}_{1}-\mathrm{Pt}-\mathrm{P}_{2}$ plane and the $\mathrm{Cl}_{1}-\mathrm{Pt}-\mathrm{Cl}_{2}$ plane is $16^{\circ}$. This solid-state geometry has been reported before, for instance with a diphosphine ligand synthesized by Armstrong et al. ${ }^{34}$

Preparation of Tetracarbonylmolybdenum(0) Complex 7. The structures found for complexes $\mathbf{5}$ and $\mathbf{6}$ clearly show that the bidentate ligand $\mathbf{1}$ is capable of forming square-planar complexes with late transition metals. We decided to broaden the scope of complexes formed with this ligand to earlier transition metals and therefore selected an octahedrally surrounded metal precursor, viz. $\mathrm{Mo}(\mathrm{CO})_{4}(\mathrm{~L})_{2}$. Ligand 1 reacted readily with $\mathrm{Mo}(\mathrm{CO})_{4}(\mathrm{pip})_{2}$ (pip = piperidine) at room temperature in $\mathrm{CH}_{2} \mathrm{Cl}_{2}$ (eq 4). After addition of acetonitrile, the light yellow precipitate $\left[\mathrm{Mo}(\mathrm{CO})_{4^{-}}\right.$ $\left.\left\{\left(\mathrm{c}-\mathrm{C}_{5} \mathrm{H}_{9}\right)_{7} \mathrm{Si}_{7} \mathrm{O}_{9}\left(\mathrm{OPPh}_{2}\right)_{2} \mathrm{OSiMePh}_{2}\right\}\right]$ could be obtained. The corresponding ${ }^{31}$ P NMR spectrum showed only one

(33) Bartczak, T. J .; Youngs, W. J .; I bers, J . A. Acta Crystallogr. 1984, C40, 1564

(34) Armstrong, S. K.; Cross, R. J .; Farrugia, L. J .; Nichols, D. A.; Perry, A. Eur. J . Inorg. Chem. 2002, 141. 


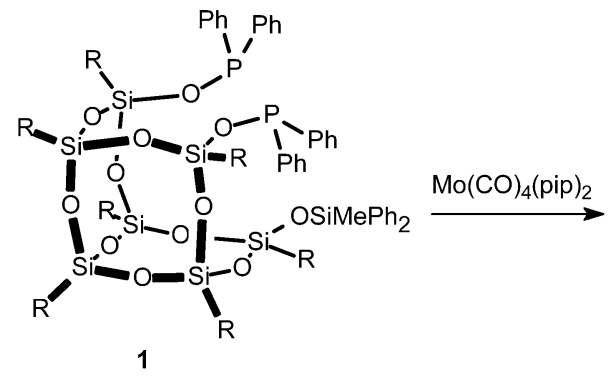

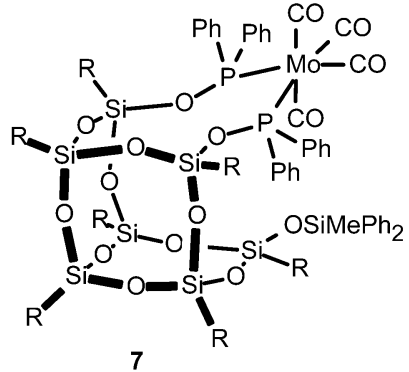

singlet at $\delta 130.4 \mathrm{ppm}$. This downfield shift with a $\Delta \delta$ value of $31.7 \mathrm{ppm}$, compared to the free ligand, is markedly different from those in the analogous $\mathrm{Pd}$ and Pt complexes, where an upfield shift is observed in the ${ }^{31} \mathrm{P}$ NMR spectrum.

In the ${ }^{13} \mathrm{C}$ NMR spectrum three triplet signals (due to $\mathrm{P}-\mathrm{C}$ coupling) are present in the carbonyl region. This implies that two CO ligands are chemically inequivalent in the complex. Most likely, both CO ligands in the equatorial (trans to P) positions are identical at $\delta 215.5 \mathrm{ppm}$, while the equatorially placed CO ligands are inequivalent at $\delta 210.2$ and $209.3 \mathrm{ppm}$. This inequivalency of the axially placed carbonyls is the result of the unsymmetrical arrangement within the molecule. The assignment of the chemical shifts is based on literature values for both sets of $\mathrm{CO}$ ligands. ${ }^{35} \mathrm{In}$ the carbonyl range of the infrared spectrum (ATR mode), three distinct vibrations are present at 2019.8, 1934.1, and $1894.6 \mathrm{~cm}^{-1}$ and one shoulder at $1872.2 \mathrm{~cm}^{-1}$, consistent with a cis-Mo(CO) $)_{4}(\mathrm{PP})$ complex. No signals of the starting material $\mathrm{Mo}(\mathrm{CO})_{4}(\mathrm{pip})_{2}$ were present in the I R spectrum, indicative that complete conversion to the diphosphinite species has taken place. We confirmed the formation of the molybdenum complex by a crystallographic study on colorless single crystals, obtained from slow diffusion of acetonitrile into a dichloromethane solution. The molecular structure of cis-[Mo(CO) $\left.)_{4}(\mathbf{1})\right](\mathbf{7})$ is depicted in Figure 5. Selected bond lengths and angles are listed in Table 5. This complex also crystallized in the triclinic space group $\mathrm{P} \overline{\mathrm{l}}$.

The geometry around the molybdenum atom of complex $\mathbf{7}$ is slightly distorted octahedral. The $\mathrm{C}_{72}-\mathrm{Mo}-\mathrm{C}_{75}$ angle is only $170.37(8)^{\circ}$, while the representative $\mathrm{C}_{73}-\mathrm{Mo}-\mathrm{C}_{74}$ angle is $91.00(8)^{\circ}$. The biteangle, $\mathrm{P}_{1}-\mathrm{Mo}_{0}-\mathrm{P}_{2}$, is $87.94(1)^{\circ}$, considerably smaller than in complexes $\mathbf{5}$ and $\mathbf{6}$. The distortion is also apparent from the angle $\mathrm{Mo}-\mathrm{C}_{72}-\mathrm{O}_{13}$ of only $173.62(17)^{\circ}$. There is only minor disorder in the molecule, as one of the cyclopentyl groups is disordered over two conformations of equal distribution. The intramol ecular $\mathrm{P}-\mathrm{P}$ distance is 3.4892(6) $\AA$, distinctly larger than for both complexes $\mathbf{5}$ and $\mathbf{6}$, a clear indication that the silsesquioxane framework of ligand $\mathbf{1}$ is quite flexible and able to accommodate various conformations. The Mo-P bond lengths of

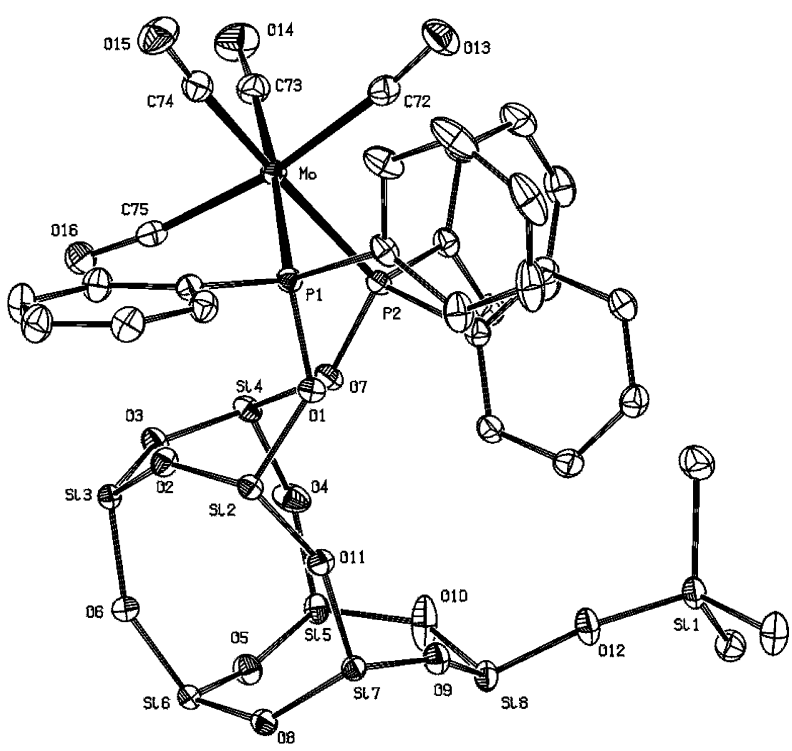

Figure 5. ORTEP representation of complex 7, cis-[Mo$(\mathrm{CO})_{4}(\mathbf{1})$ ]. Displacement ellipsoids are drawn at the $50 \%$ probability level. All hydrogen atoms and the cyclopentyl side groups are omitted for clarity.

Table 5. Selected Bond Lengths, Distances and Angles for Complex 7, cis-[Mo(CO) $\left.{ }_{4}(1)\right]$

\begin{tabular}{|c|c|c|c|}
\hline \multicolumn{4}{|c|}{ Bond Lengths ( $\AA$ ) } \\
\hline Mo- $P_{1}$ & $2.5196(5)$ & $\mathrm{P}_{1}-\mathrm{O}_{1}$ & $1.6217(13)$ \\
\hline $\mathrm{Mo}^{-\mathrm{C}_{73}}$ & $2.005(2)$ & $\mathrm{Si}_{4}-\mathrm{O}_{7}$ & $1.6467(14)$ \\
\hline $\mathrm{C}-\mathrm{O}$ & $1.14-1.15$ & $\mathrm{Si}_{8}-\mathrm{O}_{12}$ & $1.6039(16)$ \\
\hline $\mathrm{Si}_{2}-\mathrm{O}_{1}$ & $1.6462(14)$ & $\mathrm{Mo-C}_{72}$ & $2.031(2)$ \\
\hline $\mathrm{Si}_{2}-\mathrm{O}_{11}$ & $1.6191(13)$ & $\mathrm{Mo}^{-\mathrm{C}_{75}}$ & $2.044(2)$ \\
\hline$P_{1}-P_{2}$ & $3.4892(6)$ & $\mathrm{P}_{2}-\mathrm{O}_{7}$ & $1.6173(14)$ \\
\hline $\mathrm{Mo}-\mathrm{P}_{2}$ & $2.5059(5)$ & $\mathrm{Si}_{7}-\mathrm{O}_{11}$ & $1.6315(14)$ \\
\hline $\mathrm{Mo}_{74}$ & $1.999(2)$ & $\mathrm{Si}_{1}-\mathrm{O}_{12}$ & $1.6289(16)$ \\
\hline \multicolumn{4}{|c|}{ Bond Angles (deg) } \\
\hline$P_{1}-M_{0}-P_{2}$ & 87.94(1) & $\mathrm{Mo}-\mathrm{C}_{73}-\mathrm{O}_{14}$ & 176.61(19) \\
\hline $\mathrm{C}_{73}-\mathrm{Mo}_{1}-\mathrm{P}_{1}$ & $176.64(6)$ & $\mathrm{Si}_{2}-\mathrm{O}_{1}-\mathrm{P}_{1}$ & $136.59(9)$ \\
\hline $\mathrm{P}_{2}-\mathrm{Mo}_{0}-\mathrm{C}_{73}$ & 93.33(6) & $\mathrm{Si}_{1}-\mathrm{O}_{12}-\mathrm{Si}_{8}$ & 163.59(11) \\
\hline $\mathrm{Mo}-\mathrm{C}_{72}-\mathrm{O}_{13}$ & 173.62(17) & $\mathrm{C}_{72}-\mathrm{Mo}_{-} \mathrm{C}_{75}$ & $170.37(8)$ \\
\hline $\mathrm{Mo}-\mathrm{P}_{2}-\mathrm{O}_{7}$ & $115.63(5)$ & $\mathrm{P}_{1}-\mathrm{Mo}_{0}-\mathrm{C}_{74}$ & $87.90(6)$ \\
\hline $\mathrm{Si}_{2}-\mathrm{O}_{11}-\mathrm{Si}_{7}$ & 153.83(10) & $\mathrm{P}_{2}-\mathrm{Mo}-\mathrm{C}_{75}$ & $94.49(6)$ \\
\hline $\mathrm{C}_{73}-\mathrm{Mo}-\mathrm{C}_{74}$ & $91.00(8)$ & $\mathrm{Mo}-\mathrm{P}_{1}-\mathrm{O}_{1}$ & $118.35(5)$ \\
\hline $\mathrm{C}_{74}-\mathrm{Mo}_{\mathrm{O}}-\mathrm{P}_{2}$ & $174.67(6)$ & $\mathrm{Si}_{4}-\mathrm{O}_{7}-\mathrm{P}_{2}$ & 139.80(9) \\
\hline $\mathrm{P}_{1}-\mathrm{Mo}_{\mathrm{o}}-\mathrm{C}_{72}$ & $93.51(6)$ & & \\
\hline
\end{tabular}

2.5196(5) $\AA\left(\mathrm{Mo}_{0}-\mathrm{P}_{1}\right)$ and 2.5059(5) $\AA\left(\mathrm{Mo}_{\mathrm{O}}-\mathrm{P}_{2}\right)$ are in the expected range found for other molybdenum phosphinite complexes. Both Gray and co-workers ${ }^{14}$ and the group of Roesky ${ }^{15}$ have described molecular structures of complexes with the general formula $\left[\mathrm{Mo}(\mathrm{CO})_{4}\left(\mathrm{SiR}_{1} \mathrm{R}_{2^{-}}\right.\right.$ $\left.\left(\mathrm{OPP}_{2}\right)_{2}\right)$ ]. The values reported for the corresponding Mo-P bond lengths are slightly lower than those for complex 7. In comparison to the two other molybdenum phosphinite complexes described in the literature, the values found in complex $\mathbf{7}$ agree well. 35,36 The Mo-C bond lengths (average value of $\sim 2.02 \AA$ ) as well as the $\mathrm{P}-\mathrm{O}$ bond lengths of $1.6217(13) \AA\left(\mathrm{P}_{1}-\mathrm{O}_{1}\right)$ and 1.6173(14) $\AA\left(\mathrm{P}_{2}-\mathrm{O}_{7}\right)$ are all in good agreement with reported literature values. ${ }^{14,15,35,36}$ The $\mathrm{Si}-\mathrm{O}(\mathrm{P})$ bond lengths found compare well with those found in the molybdenum-silyl phosphinite complexes, reported by both Gray and Roesky.

(35) (a) Hariharasarma, M.; Lake, C. H.; Watkins, C. L.; Gray, G. M. Organometallics 1999, 18, 2593. (b) Hariharasarma, M.; Lake, C. H.; Watkins, C. L.; Gray, G. M. J . Organomet. Chem. 1999, 580, 328. (c) Gray, G. M.; Redmill, K. A. J . Organomet. Chem. 1985, 280, 105. (36) Powell, J .; Lough, A.; Wang, F. Organometallics 1992, 11, 2289. 
Preparation of Chlorocarbonylrhodium(I) Complex 8. So far, cis coordination has turned out to be the preferred mode for the novel diphosphinite ligand $\mathbf{1}$, both in square-planar and in octahedral complexes. The intramolecular $\mathrm{P}-\mathrm{P}$ distances, however, range from $3.2341(10)$ to $3.4892(6) \AA$ : i.e., a $0.25 \AA$ difference. To establish whether the chelate ring of the silsesquioxane backbone is flexible enough to accommodate bi dentate coordination to a transition metal in a trans fashion, we studied the reaction of $\mathbf{1}$ with $\left[\mathrm{RhCl}(\mathrm{CO})_{2}\right]_{2}$. U pon addition of the ligand to a $\mathrm{CH}_{2} \mathrm{Cl}_{2}$ solution of the rhodium precursor, the solution immediately turned yellow. After $6 \mathrm{~h}$ of reaction at room temperature, removal of volatiles left a clear yellow microcrystalline solid (eq 5). The 31P NMR spectrum for this complex

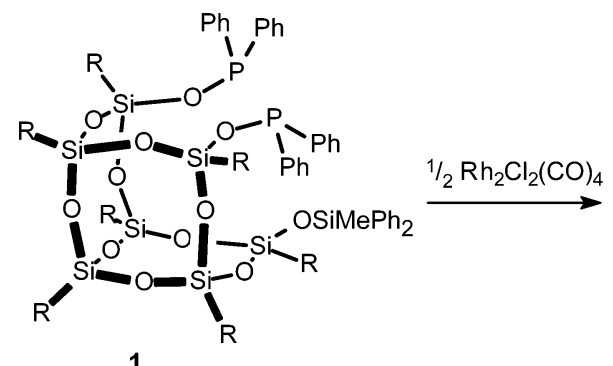

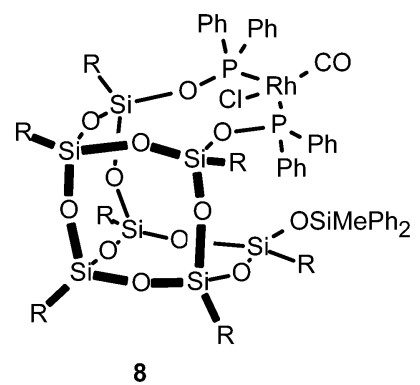

showed only a doublet at $\delta 110.1 \mathrm{ppm}$ and a coupling constant J Rh-P of $145 \mathrm{~Hz}$. The related IR spectrum (ATR mode) showed an absorption band in the carbonyl region at $v_{\mathrm{CO}} 1995 \mathrm{~cm}^{-1}$. Both measurements indicate that the complex formed is trans-[RhCl(CO)(1)]. To get structural confirmation of these spectroscopic data, single crystals were grown from $\mathrm{CH}_{2} \mathrm{Cl}_{2} / \mathrm{CH}_{3} \mathrm{CN}$ as yellow plates. These crystals turned out to be suitable for X-ray crystallography, and the molecular structure obtained for complex $\mathbf{8}$ is represented in Figure 6. Table 6 contains selected data on bond lengths and angles observed in this structure.

The geometry around the rhodium atom is slightly distorted square planar and exhibits a trans coordination of the phosphorus atoms of ligand $\mathbf{1}$. The bite angle $\mathrm{P}_{1}-\mathrm{Rh}-\mathrm{P}_{2}$ is $171.75(2)^{\circ}$, while the angle $\mathrm{Cl}_{1}-\mathrm{Rh}-\mathrm{C}_{731}$ is $175.6(2)^{\circ}$. The distortion is most pronounced in the angles $\mathrm{P}_{1}-\mathrm{Rh}-\mathrm{Cl}_{1}$ of $95.75(3)^{\circ}$ and $\mathrm{P}_{1}-\mathrm{Rh}-\mathrm{C}_{731}$ of $87.18(19)^{\circ}$. The $\mathrm{P}_{1}-\mathrm{O}-\mathrm{Si}_{1}$ angle of $147.24(12)^{\circ}$ is significantly larger than in the previous three cases, due to the trans coordination of the two phosphorus atoms. The $\mathrm{Rh}-\mathrm{P}$ bond lengths of $2.23039(7) \AA\left(\mathrm{Rh}-\mathrm{P}_{1}\right)$ and $2.2913(6) \AA\left(R h-P_{2}\right)$ are in the range reported for rhodium-phosphinite complexes. ${ }^{37-40}$ The same holds

(37) Haar, C. M.; Huang, J .; Nolan, S. P.; Petersen, J . L. Organometallics 1998, 17, 5018.

(38) Burrows, A. D.; Mahon, M. F.; Palmer, M. T.; Varrone, M. Inorg. Chem. 2002, 41, 1695.

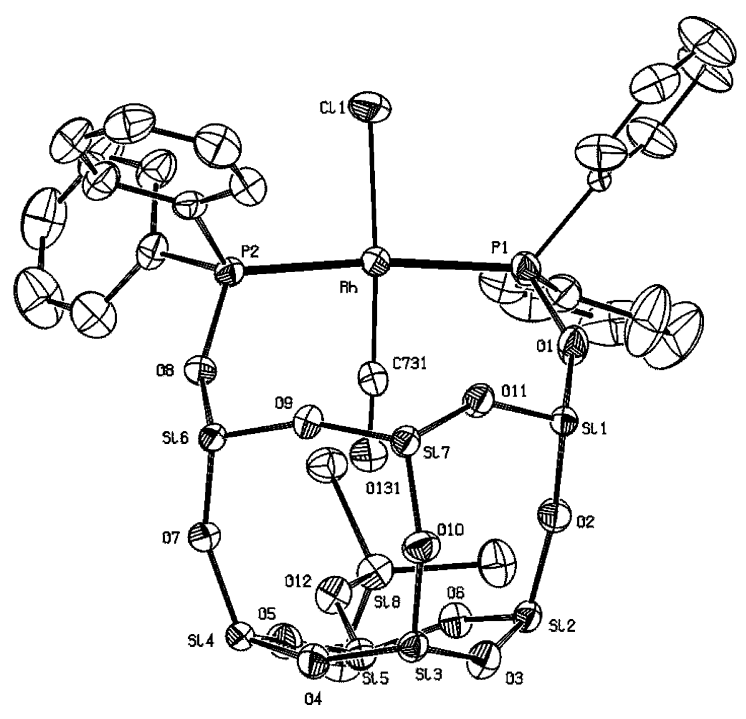

Figure 6. ORTEP representation of complex 8, trans$[\mathrm{RhCl}(\mathrm{CO})(\mathbf{1})]$. Displacement ellipsoids are drawn at the $50 \%$ probability level. All hydrogen atoms and the cyclopentyl side groups are omitted for clarity.

Table 6. Selected Bond Lengths and Angles for Complex 8, trans-[RhCl(CO)(1)]

\begin{tabular}{|c|c|c|c|}
\hline \multicolumn{4}{|c|}{ Bond Lengths $(\AA)$} \\
\hline $\begin{array}{l}\mathrm{Rh}-\mathrm{P}_{1} \\
\mathrm{Rh}-\mathrm{C}_{731} \\
\mathrm{P}_{2}-\mathrm{O}_{8} \\
\mathrm{Si}_{1}-\mathrm{O}_{2} \\
\mathrm{Si}_{8}-\mathrm{O}_{12} \\
\mathrm{Rh}-\mathrm{P}_{2} \\
\mathrm{C}_{731}-\mathrm{O}_{131}\end{array}$ & $\begin{array}{l}2.3039(7) \\
1.793(5) \\
1.6108(16) \\
1.6091(18) \\
1.6390(18) \\
2.2913(6) \\
1.152(6)\end{array}$ & $\begin{array}{l}\mathrm{Si}_{1}-\mathrm{O}_{1} \\
\mathrm{Si}_{2}-\mathrm{O}_{2} \\
\mathrm{P}_{1}-\mathrm{P}_{2} \\
\mathrm{Rh}-\mathrm{Cl}_{1} \\
\mathrm{P}_{1}-\mathrm{O}_{1} \\
\mathrm{Si}_{6}-\mathrm{O}_{8} \\
\mathrm{Si}_{5}-\mathrm{O}_{12}\end{array}$ & $\begin{array}{l}1.6365(19) \\
1.6171(18) \\
4.5832(9) \\
2.3483(15) \\
1.6023(19) \\
1.6504(16) \\
1.6201(18)\end{array}$ \\
\hline \multicolumn{4}{|c|}{ Bond Angles (deg) } \\
\hline $\begin{array}{l}\mathrm{P}_{1}-\mathrm{Rh}-\mathrm{P}_{2} \\
\mathrm{C}_{731}-\mathrm{Rh}-\mathrm{P}_{2} \\
\mathrm{Rh}-\mathrm{C}_{731}-\mathrm{O}_{131} \\
\mathrm{P}_{1}-\mathrm{O}_{1}-\mathrm{Si}_{1} \\
\mathrm{Si}_{5}-\mathrm{O}_{12}-\mathrm{Si}_{8} \\
\mathrm{C}_{731}-\mathrm{Rh}-\mathrm{Cl}_{1} \\
\mathrm{P}_{1}-\mathrm{Rh}-\mathrm{Cl}_{1}\end{array}$ & $\begin{array}{c}171.75(2) \\
87.15(19) \\
174.8(6) \\
147.24(12) \\
137.30(11) \\
175.6(2) \\
95.75(3)\end{array}$ & $\begin{array}{l}\mathrm{Rh}-\mathrm{P}_{1}-\mathrm{O}_{1} \\
\mathrm{P}_{2}-\mathrm{O}_{8}-\mathrm{Si}_{6} \\
\mathrm{C}_{731}-\mathrm{Rh}-\mathrm{P}_{1} \\
\mathrm{P}_{2}-\mathrm{Rh}-\mathrm{Cl}_{1} \\
\mathrm{Rh}-\mathrm{P}_{2}-\mathrm{O}_{8} \\
\mathrm{Si}_{1}-\mathrm{O}_{2}-\mathrm{Si}_{2}\end{array}$ & $\begin{array}{c}112.83(7) \\
138.18(11) \\
87.18(19) \\
90.28(3) \\
113.21(6) \\
162.21(12)\end{array}$ \\
\hline
\end{tabular}

for the $\mathrm{Rh}-\mathrm{Cl}_{1}$ and $\mathrm{Rh}-\mathrm{C}_{731}$ bond lengths, although the latter falls short compared with the values of around $1.82-1.83 \AA$ found in the literature. ${ }^{37,38}$ The lengths for the phosphorus- oxygen bonds $\mathrm{P}_{1}-\mathrm{O}_{1}(1.6023(19) \AA)$ and $\mathrm{P}_{1}-\mathrm{O}_{8}(1.6108(16 \AA)$ are in agreement with reported values for other phosphinite-containing $\mathrm{Rh}$ complexes. ${ }^{37-40}$ The various silicon-oxygen bonds present in complex $\mathbf{8}$ are only slightly shorter than those in complexes 5-7. The $\mathrm{Cl}$ and $\mathrm{CO}$ ligands are both disordered over two positions with equal distributions. The intramolecular $\mathrm{P}-\mathrm{P}$ distance in complex $\mathbf{8}$ is significantly larger at 4.5832(9) $\AA$ than the distances found in complexes 5-7 as a result of the trans disposition.

\section{Conclusions}

We have shown the successful synthesis of the new diphosphinite compound 1, based on an incompletely condensed silsesquioxane framework, as well as its

(39) van der Slot, S. C.; Kamer, P. C. J .; van Leeuwen, P. W. N. M.; Fraanje, J .; Goubitz, K.; Lutz, M.; Spek, A. L. Organometallics 2000, 19, 2504

(40) (a) Kempe, R.; Schwarze, M.; Selke, R. Z. Kristallogr. 1995, 210, 555. (b) Kempe, R.; Spannenberg, A.; Heller, D. Z. Kristallogr. 1998, 213, 631. (c) Kempe, R.; Spannenberg, A.; Heller, D.; Kadyrov, R.; Fehring, V. Z. Kristallogr. 2001, 216, 157. 
diselenide derivative 2. By DFT calculations a first approximation to the el ectron-withdrawing character of siloxy-based ligand backbones such as silsesquioxanes is provided. Ligand $\mathbf{1}$ showed good reactivity toward various transition metals. With palladium, platinum, or molybdenum, the cis complex is the preferred geometry, as shown by spectroscopic measurements as well as by X-ray crystallography on single crystals of the three complexes. However, in the analogous $\mathrm{RhCl}(\mathrm{CO})$ (1) complex the phosphinite moieties are coordinated in a trans fashion. This implies that the silsesquioxane framework is flexible enough to accommodate different geometries. We believe this first example of the usage of silsesquioxanes as building blocks for ligand backbones will provide new opportunities for ligand design and coordination chemistry. The synthesis of other novel silsesquioxane-functionalized ligands and their application in transition-metal-mediated catalysis are currently being studied. Furthermore, DFT studies on the metal complexes of the described model compounds are ongoing.

\section{Experimental Section}

All manipulations were carried out under argon using standard Schlenk techniques. Chemicals were purchased from Merck, Acros, or Aldrich, and solvents were either taken as HPLC grade from an argon-flushed column, packed with al uminum oxide, or distilled under argon prior to use over an appropriate drying agent. NMR spectra were recorded at room temperature on a Varian Mercury $400 \mathrm{MHz}$ spectrometer. Chemical shifts are given in ppm, and spectra are referenced to $\mathrm{CDCl}_{3}\left({ }^{1} \mathrm{H},{ }^{13} \mathrm{C}\left\{{ }^{1} \mathrm{H}\right\}\right)$ or $85 \% \mathrm{H}_{3} \mathrm{PO}_{4}\left({ }^{31} \mathrm{P}\left\{{ }^{1} \mathrm{H}\right\}\right)$. FT-IR spectra weretaken on an AVATAR ESP $360 \mathrm{FTIR}$ spectrometer. $\mathrm{PtCl}_{2-}$ (cod) ${ }^{41} \mathrm{Mo}(\mathrm{CO})_{4}\left(\mathrm{pip}_{2},{ }^{42}\right.$ and $\left(\mathrm{c}-\mathrm{C}_{5} \mathrm{H}_{9}\right)_{7} \mathrm{Si}_{7} \mathrm{O}_{9}(\mathrm{OSiMePh})(\mathrm{OH})_{2}$ (A) ${ }^{17}$ were prepared according to literature procedures.

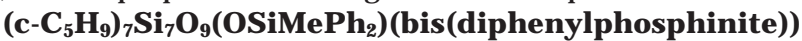
(1). A (1.03 g, $0.96 \mathrm{mmol}$ ) was dissolved with heating in 20 $\mathrm{mL}$ of toluene, and $\mathrm{NEt}_{3}(0.19 \mathrm{~g}, 1.92 \mathrm{mmol})$ was added. With stirring at $-15{ }^{\circ} \mathrm{C} \mathrm{ClPPh}_{2}(0.42 \mathrm{~g}, 1.91 \mathrm{mmol})$ in $3 \mathrm{~mL}$ of toluene was added dropwise via syringe, and the reaction mixture was warmed to room temperature. All solvents were removed in vacuo, and the product was extracted with $10 \mathrm{~mL}$ of hexanes. After removal of the solvents $\mathbf{1}$ was obtained as a solid. Yield: $86 \%(1.19 \mathrm{~g}, 0.83 \mathrm{mmol}) .{ }^{1} \mathrm{H}$ NMR $\left(\mathrm{CDCl}_{3}\right): \delta 7.53$ (dd, $\left.8 \mathrm{H}, \mathrm{H}_{\text {ortho }} \mathrm{PPh}_{2},{ }^{1} \mathrm{j}=7.6 \mathrm{~Hz},{ }^{2} \mathrm{j}=1.2 \mathrm{~Hz}\right), 7.44(\mathrm{~m}, 4 \mathrm{H}$, $\left.\mathrm{H}_{\text {ortho }} \mathrm{SiMePh}_{2}\right), 7.29(\mathrm{~m}, 6 \mathrm{H}, \mathrm{SiMePh}), 7.16\left(\mathrm{~m}, 12 \mathrm{H}, \mathrm{PPh}_{2}\right)$, 1.80-1.34 (br m, c- $\mathrm{C}_{5} \mathrm{H}_{9}$ ), 1.02 (dsextet, $6 \mathrm{H}, \mathrm{c}^{-\mathrm{C}_{5} \mathrm{H}_{9}, ~}{ }^{1} \mathrm{~J}=4.4$ $\mathrm{Hz}$, ${ }^{2} \mathrm{~J}=1.2 \mathrm{~Hz}$ ), 0.90 (dquintet, $6 \mathrm{H}, \mathrm{c}^{-} \mathrm{C}_{5} \mathrm{H}_{9},{ }^{\mathrm{I}} \mathrm{j}=4.4 \mathrm{~Hz}$, ${ }^{2} \mathrm{~J}=$ $1.2 \mathrm{~Hz}), 0.53\left(\mathrm{~s}, 3 \mathrm{H}, \mathrm{SiMePh}_{2}\right) .{ }^{13} \mathrm{C} \mathrm{NMR}\left(\mathrm{CDCl}_{3}\right): \delta 137.9$, $134.2,130.0,129.9(\mathrm{~d}, \mathrm{~J} \mathrm{p}-\mathrm{C}=8.5 \mathrm{~Hz}), 129.6,129.0,128.5(\mathrm{~d}$,

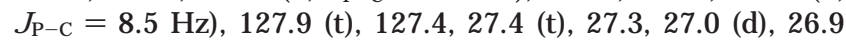
(d), 24.1, 24.0, 23.5, 23.4, $22.4\left(1: 2: 2: 1: 1\right.$ ratio for $\left.\mathrm{C}_{\text {ipso }} \mathrm{H}\right),-0.5$ $\left(\mathrm{SiMePh}_{2}\right) .{ }^{31} \mathrm{P} \mathrm{NMR}\left(\mathrm{CDCl}_{3}\right): \delta 98.7$ (s). ${ }^{29} \mathrm{Si} \mathrm{NMR}\left(\mathrm{CDCl}_{3}\right): \delta$ $-11.26,-57.44,-65.60,-65.72,-67.13,-67.80$. Anal. Calcd for $\mathrm{C}_{72} \mathrm{H}_{96} \mathrm{O}_{12} \mathrm{P}_{2} \mathrm{Si}_{8}: \mathrm{C}, 60.05 ; \mathrm{H}, 6.72$. Found: $\mathrm{C}, 60.19 ; \mathrm{H}, 6.68$.

$\left.\left(\mathrm{c}-\mathrm{C}_{5} \mathrm{H}_{9}\right)_{7} \mathrm{Si}_{7} \mathrm{O}_{9} \mathrm{OSiMePh}_{2}\right)$ (bis((diphenylphosphino)oxy) selenide) (2). 1 (65.9 mg, $45.8 \mu \mathrm{mol}$ ) was dissolved in 5 $\mathrm{mL}$ of toluene, and an excess of black selenium was added. The reaction mixture was stirred for $1 \mathrm{~h}$ at $100^{\circ} \mathrm{C}$. Removal of the solution from unreacted selenium by cannula was followed by evaporation to dryness, leaving 2 as a pinkish solid. Yield: $98 \%(71.7 \mathrm{mg}, 44.8 \mu \mathrm{mol}) .{ }^{1} \mathrm{H} \mathrm{NMR}\left(\mathrm{CDCl}_{3}\right): \delta 7.84-$ $7.75\left(\mathrm{~m}, 8 \mathrm{H}, \mathrm{H}_{\text {ortho }} \mathrm{PPh}_{2}\right), 7.49$ (dd, 4H, $\mathrm{H}_{\text {ortho }} \mathrm{SiMePh}_{2},{ }^{1} \mathrm{~J}=$ $\left.7.6 \mathrm{~Hz},{ }^{2} \mathrm{j}=1.6 \mathrm{~Hz}\right), 7.35-7.30\left(\mathrm{~m}, 6 \mathrm{H}, \mathrm{SiMePh}_{2}\right), 7.11$ (br t, $\left.12 \mathrm{H}, \mathrm{PPh}_{2}\right), 178\left(\mathrm{~m}, \mathrm{c}-\mathrm{C}_{5} \mathrm{H}_{9}\right), 1.60-1.35\left(\mathrm{~m}, \mathrm{c}-\mathrm{C}_{5} \mathrm{H}_{9}\right), 0.98(\mathrm{~m}$,

(41) Clark, H. C.; Manzer, L. E. J . Organomet. Chem. 1973, 59, 411.

(42) Darensbourg, D. J .; Kump, R. L. Inorg. Chem. 1978, 17, 2680.
$\left.\mathrm{C}^{-} \mathrm{C}_{5} \mathrm{H}_{9}\right), 0.83\left(\mathrm{~m}, \mathrm{c}-\mathrm{C}_{5} \mathrm{H}_{9}\right), 0.16\left(\mathrm{~s}, \mathrm{SiMePh}_{2}\right) .{ }^{13} \mathrm{C} \mathrm{NMR}$ $\left(\mathrm{CDCl}_{3}\right): \delta 137.4,137.1\left(\mathrm{~d},{ }^{1} \mathrm{~J}=4.5 \mathrm{~Hz}\right), 136.1\left(\mathrm{~d},{ }^{1} \mathrm{~J}=4.5\right.$ $\mathrm{Hz}), 134.0,131.3(\mathrm{~d}, \mathrm{l} J=3.0 \mathrm{~Hz}), 131.2(\mathrm{~d}, \mathrm{~J}=3.0 \mathrm{~Hz}), 130.8$ $\left(d,{ }^{1} \mathrm{~J}=10.7 \mathrm{~Hz}\right), 130.7\left(\mathrm{~d},{ }^{1} \mathrm{~J}=10.7 \mathrm{~Hz}\right), 129.5,128.2\left(\mathrm{~d},{ }^{1} \mathrm{~J}=\right.$ $6.8 \mathrm{~Hz}), 128.1\left(\mathrm{~d},{ }^{1} \mathrm{~J}=6.8 \mathrm{~Hz}\right), 127.6,27.6,27.5,27.3,27.2$, 26.9 (d), 26.8, 26.7, 25.1, 24.3, 23.7, 23.6, 22.5, (2:1:2:1:1 ratio for $\left.\mathrm{C}_{\mathrm{ipso}} \mathrm{H}\right),-0.85\left(\mathrm{SiMePh}_{2}\right)$. ${ }^{31} \mathrm{P} \mathrm{NMR}\left(\mathrm{CH}_{2} \mathrm{Cl}_{2}\right): \delta 69.8(\mathrm{~s}$, J se-P $=815 \mathrm{~Hz}) .{ }^{29} \mathrm{Si} \mathrm{NMR}\left(\mathrm{CDCl}_{3}\right): \delta-10.26,-63.69,-63.72$, -65.56, -66.23, -66.32. Anal. Calcd for $\mathrm{C}_{72} \mathrm{H}_{96} \mathrm{O}_{12} \mathrm{P}_{2} \mathrm{Se}_{2} \mathrm{Si}_{8}$ : C, 54.11; $\mathrm{H}, 6.05$. Found: $\mathrm{C}, 54.02 ; \mathrm{H}, 6.12$.

Complex $\mathbf{P d C l}_{2}$ (1) (5). $\mathrm{PdCl}_{2}\left(\mathrm{C}_{6} \mathrm{H}_{5} \mathrm{CN}\right)_{2}$ (19.0 mg, 50.0 $\mu \mathrm{mol})$ and $\mathbf{1}(72.0 \mathrm{mg}, 50.0 \mu \mathrm{mol})$ were dissolved in $5 \mathrm{~mL}$ of $\mathrm{CH}_{2} \mathrm{Cl}_{2}$ and stirred for $2 \mathrm{~h}$ at room temperature. Solvents were then evaporated in vacuo to leave $\mathbf{5}$ as a pure yellow solid. Yield: 95\% (76.8 mg, $47.5 \mu \mathrm{mol}$ ). Layering with $\mathrm{CH}_{2} \mathrm{Cl}_{2} /$ $\mathrm{CH}_{3} \mathrm{CN}$ under a slight argon flow gave yellow rectangular single crystals, suitable for X-ray analysis. ${ }^{1} \mathrm{H} \mathrm{NMR}\left(\mathrm{CDCl}_{3}\right): \delta$ $7.73\left(\mathrm{dd}, 4 \mathrm{H}, \mathrm{J}_{1}=12.8 \mathrm{~Hz}, \mathrm{~J}_{2}=7.2 \mathrm{~Hz}\right), 7.44\left(\mathrm{~d}, 4 \mathrm{H}, \mathrm{J}_{1}=7.2\right.$ $\mathrm{Hz}), 7.37\left(\mathrm{t}, 8 \mathrm{H}, \mathrm{J}_{1}=7.2 \mathrm{~Hz}\right), 7.26\left(\mathrm{t}, 8 \mathrm{H}, \mathrm{J}_{1}=7.2 \mathrm{~Hz}\right), 6.99(\mathrm{t}$, $\left.4 \mathrm{H}, \mathrm{J}_{1}=7.2 \mathrm{~Hz}\right), 6.91\left(\mathrm{t}, 2 \mathrm{H}, \mathrm{J}_{1}=7.2 \mathrm{~Hz}\right), 1.83\left(\mathrm{br} \mathrm{s}, \mathrm{c}-\mathrm{C}_{5} \mathrm{H}_{9}\right)$, 1.60 (br s), 1.31 (br s), $1.05\left(\mathrm{~m}, \mathrm{c}-\mathrm{C}_{5} \mathrm{H}_{9}\right), 0.83\left(\mathrm{~m}, \mathrm{c}-\mathrm{C}_{5} \mathrm{H}_{9}\right), 0.03-$ $\left(\mathrm{s}, \mathrm{SiMePh} \mathrm{H}_{2}\right) .{ }^{13} \mathrm{C} \mathrm{NMR}\left(\mathrm{CDCl}_{3}\right): \delta 137.1,133.9,132.4(\mathrm{~d}, \mathrm{~J} \mathrm{P}-\mathrm{C}$ $=5.2 \mathrm{~Hz}), 132.1,131.2,130.6(\mathrm{~d}, \mathrm{~J} \mathrm{p}-\mathrm{C}=5.2 \mathrm{~Hz}), 130.4,129.5$, $129.1,128.1\left(\mathrm{~d}, \mathrm{~J}_{\mathrm{P}-\mathrm{C}}=5.2 \mathrm{~Hz}\right), 127.5,127.3(\mathrm{~d}, \mathrm{~J} \mathrm{p}-\mathrm{C}=5.2 \mathrm{~Hz})$, 27.6, 27.3, 27.4, 27.2, 27.1, 27.0, 26.9, 26.7 (d), 24.8, 23.4 (d), 23.2, $22.2\left(2: 1: 1: 2: 1\right.$ ratio for $\left.\mathrm{C}_{\text {ipso }} \mathrm{H}\right),-0.9\left(\mathrm{SiMePh}_{2}\right) .{ }^{31} \mathrm{P} N M R$ $\left(\mathrm{CDCl}_{3}\right): \delta 91.8$ (s). ${ }^{29} \mathrm{Si} \mathrm{NMR}\left(\mathrm{CDCl}_{3}\right): \delta-10.73,-64.01$, $-64.17,-65.56,-66.01,-66.99$. Anal. Calcd for $\mathrm{C}_{72} \mathrm{H}_{96} \mathrm{O}_{12} \mathrm{P}_{2^{-}}$ PdSi 8 : C, 53.46; H, 5.98. Found: C, 53.58; H, 6.10.

Complex $\mathbf{P t C l}_{\mathbf{2}}$ (1) (6). $\mathrm{PtCl}_{2}$ (cod) (15.5 mg, $41.5 \mu \mathrm{mol}$ ) and $\mathbf{1}\left(59.7 \mathrm{mg}, 41.5 \mu \mathrm{mol}\right.$ ) were dissolved in $5 \mathrm{~mL}$ of $\mathrm{CH}_{2} \mathrm{Cl}_{2}$ and stirred for $2 \mathrm{~h}$ at room temperature. The solvent was removed in vacuo. Subsequently the remaining traces of solvent were removed by extracting two times with $5 \mathrm{~mL}$ of hexanes to leave 6 as a white powder. Yield: $92 \%$ (65.1 mg, $38.5 \mu \mathrm{mol})$. U pon slow diffusion of acetonitrile into a dichloromethane solution of this compound, colorless cubic single crystals were obtained, suitable for X-ray analysis. ${ }^{1} \mathrm{H} \mathrm{NMR}\left(\mathrm{CDCl}_{3}\right): \delta 7.69(\mathrm{dd}, 4 \mathrm{H}$, $\left.\mathrm{J}_{1}=12.0 \mathrm{~Hz}, \mathrm{~J}_{2}=7.6 \mathrm{~Hz}\right), 7.42\left(\mathrm{~d}, 4 \mathrm{H}, \mathrm{J}_{1}=6.8 \mathrm{~Hz}\right), 7.36(\mathrm{t}$, $\left.4 \mathrm{H}, \mathrm{J}_{1}=6.8 \mathrm{~Hz}\right), 7.33\left(\mathrm{~d}, 4 \mathrm{H}, \mathrm{J}_{1}=7.2 \mathrm{~Hz}\right), 7.26\left(\mathrm{~d}, 4 \mathrm{H}, \mathrm{J}_{1}=\right.$ $7.2 \mathrm{~Hz}), 7.24\left(\mathrm{t}, 4 \mathrm{H}, \mathrm{J}_{1}=7.6 \mathrm{~Hz}\right), 6.97\left(\mathrm{t}, 4 \mathrm{H}, \mathrm{J}_{1}=7.2 \mathrm{~Hz}\right)$, $6.88\left(\mathrm{t}, 2 \mathrm{H}, \mathrm{J}_{1}=7.2 \mathrm{~Hz}\right), 1.97-1.17\left(\mathrm{br} \mathrm{m}, \mathrm{c}-\mathrm{C}_{5} \mathrm{H}_{9}\right), 1.04$ (quintet, $\left.\mathrm{J}_{1}=8.8 \mathrm{~Hz}, \mathrm{c}-\mathrm{C}_{5} \mathrm{H}_{9}\right), 0.83\left(\mathrm{~m}, \mathrm{c}-\mathrm{C}_{5} \mathrm{H}_{9}\right), 0.20(\mathrm{br} \mathrm{m}$, $\left.\mathrm{C}^{-} \mathrm{C}_{5} \mathrm{H}_{9}\right),-0.03(\mathrm{~s}, \mathrm{SiMePh}) .{ }^{13} \mathrm{C} N M R\left(\mathrm{CDCl}_{3}\right): \delta 137.1,133.9$, 132.7 (d), 132.3, 131.1, 130.6 (d), 130.2, 129.5, 128.7, 127.9 (d), $127.5,127.0$ (d), 30.9, 28.0, 27.6, 27.5, 27.4, 27.3, 27.1 (d), 26.9, 26.8, 26.7, 24.8, 23.5 (d), 23.2, $22.2\left(1: 1: 1: 2: 2\right.$ ratio for $\left.\mathrm{C}_{\text {ipso }} \mathrm{H}\right)$, $-1.0\left(\mathrm{SiMePh}_{2}\right)$. ${ }^{31} \mathrm{P} \mathrm{NMR}\left(\mathrm{CDCl}_{3}\right): \delta 64.5(\mathrm{~d}, \mathrm{~J} \mathrm{Pt}-\mathrm{P}=4246 \mathrm{~Hz})$. ${ }^{29} \mathrm{Si} \mathrm{NMR}\left(\mathrm{CDCl}_{3}\right)$ : $\delta-10.64,-64.13,-64.96,-65.05,-65.86$, -66.42. Anal. Calcd for $\mathrm{C}_{72} \mathrm{H}_{96} \mathrm{O}_{12} \mathrm{P}_{2} \mathrm{PtSi}_{8}$ : C, 50.69; $\mathrm{H}, 5.67$. Found: C, 50.75; $\mathrm{H}, 5.62$.

Complex $\mathrm{Mo}(\mathrm{CO})_{4}(\mathbf{1})$ (7). $\mathrm{Mo}(\mathrm{CO})_{4}(\mathrm{pip})_{2}(53.5 \mathrm{mg}, 141.4$ $\mu \mathrm{mol}$ ) and 1 (204.6 mg, $142.0 \mu \mathrm{mol}$ ) were dissolved in $10 \mathrm{~mL}$ of $\mathrm{CH}_{2} \mathrm{Cl}_{2}$ and stirred for $2 \mathrm{~h}$ at room temperature. The solvent was concentrated to approximately $3 \mathrm{~mL}$ in vacuo. A $5 \mathrm{~mL}$ portion of acetonitrile was added to precipitate the desired product as an off-white powder. After isolation of the powder, further washing with $4 \mathrm{~mL}$ of acetonitrile followed by drying in vacuo yiel ded 7 as a white powder. Yield: 78\% (110.8 mg, $182.6 \mu \mathrm{mol}$ ). U pon sl ow diffusion of acetonitrile into a dichloromethane solution, yel low parallelepiped single crystals were obtained, suitable for X-ray analysis. ${ }^{1} \mathrm{H} \mathrm{NMR}\left(\mathrm{CDCl}_{3}\right): \delta 7.70$ $(\mathrm{m}, 4 \mathrm{H}), 7.49$ (dd, 4H, lJ $\left.=7.6 \mathrm{~Hz},{ }^{2} \mathrm{~J}=1.2 \mathrm{~Hz}\right), 7.41(\mathrm{t}, 2 \mathrm{H}$, I $=7.6 \mathrm{~Hz}, 2 \mathrm{~J}=1.2 \mathrm{~Hz}), 7.34\left(\mathrm{dt}, 10 \mathrm{H}, 1 \mathrm{~J}=7.6 \mathrm{~Hz},{ }^{2} \mathrm{~J}=3.2\right.$ $\mathrm{Hz}), 7.17(\mathrm{dd}, 4 \mathrm{H}), 7.00\left(\mathrm{t}, 4 \mathrm{H},{ }^{1} \mathrm{~J}=7.6 \mathrm{~Hz}\right), 6.68\left(\mathrm{t}, 2 \mathrm{H},{ }^{1} \mathrm{~J}=\right.$ 7.6 Hz), 1.95-1.14 (br m, c- $\mathrm{C}_{5} \mathrm{H}_{9}$ ), 1.06 (quintet, ${ }^{1} \mathrm{~J}=8.8 \mathrm{~Hz}$, $\left.\mathrm{c}-\mathrm{C}_{5} \mathrm{H}_{9}\right), 0.84\left(\mathrm{~m}, \mathrm{c}-\mathrm{C}_{5} \mathrm{H}_{9}\right), 0.1\left(\mathrm{~s}, \mathrm{SiMePh}_{2}\right) .{ }^{13} \mathrm{C} N M R$ $\left(\mathrm{CDCl}_{3}\right): \delta 215.5(\mathrm{t}, \mathrm{J} \mathrm{P}-\mathrm{C}=10.5 \mathrm{~Hz}), 210.2(\mathrm{t}, \mathrm{J} \mathrm{p}-\mathrm{C}=11.5 \mathrm{~Hz})$, $209.3\left(t, J_{P-C}=10.0 \mathrm{~Hz}\right), 142.6\left(t, J_{P-C}=14.6 \mathrm{~Hz}\right), 141.5(\mathrm{t}$, $\mathrm{J} P-\mathrm{C}=19.9 \mathrm{~Hz}), 137.5,134.0,131.3(\mathrm{t}, \mathrm{J} \mathrm{P}-\mathrm{C}=7.5 \mathrm{~Hz}), 130.3$, $129.5,128.8(t, J$ P-C $=7.5 \mathrm{~Hz}), 128.3,127.8(\mathrm{t}), 127.6(\mathrm{t}), 127.6$, 
Table 7. Selected Crystallographic Data for Complexes 5-8

\begin{tabular}{|c|c|c|c|c|}
\hline & 5 & 6 & 7 & 8 \\
\hline $\begin{array}{l}\text { formula } \\
\text { fw }\end{array}$ & $\begin{array}{l}\mathrm{C}_{72} \mathrm{H}_{96} \mathrm{Cl}_{2} \mathrm{O}_{12} \mathrm{P}_{2} \mathrm{PdSi}_{8} \\
1617.45^{\mathrm{a}}\end{array}$ & $\begin{array}{l}\mathrm{C}_{72} \mathrm{H}_{96} \mathrm{Cl}_{2} \mathrm{O}_{12} \mathrm{P}_{2} \mathrm{PtSi}_{8} \\
1706.14^{\mathrm{a}}\end{array}$ & $\begin{array}{l}\mathrm{C}_{76} \mathrm{H}_{96} \mathrm{Cl}_{2} \mathrm{O}_{16} \mathrm{P}_{2} \mathrm{MoSi}_{8} \cdot \mathrm{CH}_{2} \mathrm{Cl}_{2} \\
1747.12\end{array}$ & $\begin{array}{l}\mathrm{C}_{73} \mathrm{H}_{94} \mathrm{ClO}_{13} \mathrm{P}_{2} \mathrm{RhSi}_{8} \\
1606.55\end{array}$ \\
\hline cryst size (mm) & $0.12 \times 0.15 \times 0.30$ & $0.06 \times 0.24 \times 0.51$ & $0.49 \times 0.35 \times 0.30$ & $0.33 \times 0.29 \times 0.09$ \\
\hline cryst syst & triclinic & triclinic & triclinic & monodinic \\
\hline space group & $\mathrm{P} \overline{1}$ (No. 2) & $\mathrm{P} \overline{1}$ (No. 2) & $\mathrm{P} \overline{1}$ (No. 2) & $\mathrm{P} 21 / \mathrm{a}$ (No. 14) \\
\hline $\mathrm{a}(\AA)$ & $12.9272(1)$ & $12.9593(1)$ & $13.5557(5)$ & $20.2345(8)$ \\
\hline$b(\AA)$ & $17.7140(2)$ & $17.6366(1)$ & $17.5982(7)$ & $15.8819(6)$ \\
\hline$c(\AA)$ & $19.4640(2)$ & $19.4061(2)$ & $19.2276(7)$ & $24.428(1)$ \\
\hline$\alpha$ (deg) & $89.1056(4)$ & $88.9667(3)$ & $73.275(1)$ & \\
\hline$\beta$ (deg) & 76.6436(4) & $76.5243(3)$ & $79.557(1)$ & $91.356(1)$ \\
\hline$\gamma$ (deg) & $78.2285(5)$ & $77.4749(5)$ & 78.516(1) & \\
\hline$V\left(\AA^{3}\right)$ & $4243.03(7)$ & 4208.19(6) & $4267.2(3)$ & $7848.0(5)$ \\
\hline$\mu(\mathrm{M} \circ \mathrm{K} \alpha)\left(\mathrm{mm}^{-1}\right)$ & $0.485^{\mathrm{a}}$ & $1.936^{\mathrm{a}}$ & 4.28 & 4.73 \\
\hline Z & 2 & 2 & 2 & 4 \\
\hline $\bar{d}_{\text {calcd }}\left(\mathrm{g} \mathrm{cm}^{-3}\right)$ & $1.266^{a}$ & $1.347^{a}$ & 1.360 & 1.360 \\
\hline $\mathrm{T}(\mathrm{K})$ & 150 & 150 & 100 & 160 \\
\hline total no. of rflns & 53944 & 59874 & 40663 & 67424 \\
\hline no. of unique rflns $\left(R_{\text {int }}\right)^{b}$ & $14934(0.085)$ & 19015 (0.052) & $21387(0.0185)^{c}$ & $18032(0.0372)^{c}$ \\
\hline wR2 $\left(F^{2}\right)(\text { all data })^{b}$ & 0.1132 & 0.0777 & 0.1057 & 0.1111 \\
\hline$\lambda(\AA)$ & 0.71073 & 0.71073 & 0.71073 & 0.71073 \\
\hline $\mathrm{R} 1(\mathrm{~F})^{\mathrm{b}}$ & 0.0447 & 0.0329 & 0.0375 & 0.0421 \\
\hline$F(000)$ & $1692^{a}$ & $1756^{a}$ & 1828 & 3368 \\
\hline
\end{tabular}

${ }^{a}$ Calculated without contribution of solvent. ${ }^{b} R_{\text {int }}=\sum\left[\mid F_{o}{ }^{2}-F_{o}{ }^{2}(\right.$ mean $\left.) \mid\right] / \Sigma\left[F_{o}{ }^{2}\right] . w R 2\left(F^{2}\right)=\left[\Sigma\left[w\left(F_{o}^{2}-F_{c}^{2}\right)^{2}\right] / \Sigma\left[w\left(F_{o}^{2}\right)^{2}\right]\right]^{1 / 2} \cdot R 1(F)=$ $\sum\left(|| \mathrm{F}_{\mathrm{o}}|-| \mathrm{F}_{\mathrm{c}} \mid\right) / \Sigma\left|\mathrm{F}_{\mathrm{o}}\right| .{ }^{\mathrm{C}} \mathrm{F}_{\mathrm{o}} \geq 4.0 \sigma\left(\mathrm{F}_{\mathrm{o}}\right)$ and 975 parameters.

$27.8,27.6,27.5,27.4,27.3(d), 27.1$ (d), 27.0, 26.9, 26.7, 26.6 (d), 25.1, 24.1, 23.6, 22.4, $22.3\left(1: 2: 2: 1: 1\right.$ ratio for $\left.\mathrm{C}_{\text {ipso }} \mathrm{H}\right),-1.2$ $\left(\mathrm{SiMePh}_{2}\right)$. ${ }^{31} \mathrm{P} \mathrm{NMR}\left(\mathrm{CDCl}_{3}\right): \delta 130.4$ (s). ${ }^{29} \mathrm{Si} \mathrm{NMR}\left(\mathrm{CDCl}_{3}\right)$ : $\delta-11.14,-64.71,-65.23,-65.90,-66.18,-66.49$. IR (ATR mode, carbonyl region): $v 1872.2$ (s), 1894.6 (st) 1934.1 (m), $2019.8(\mathrm{~m}) \mathrm{cm}^{-1}$. Anal. Calcd for $\mathrm{C}_{76} \mathrm{H}_{96} \mathrm{MoO}_{16} \mathrm{P}_{2} \mathrm{Si}_{8}$ : C, 55.39; $H$, 5.87. Found: C, 55.18; $H, 5.83$.

Complex $\mathbf{R h}(\mathrm{CI})(\mathrm{CO})(\mathbf{1})$ (8). $\left[\mathrm{Rh}(\mu-\mathrm{Cl})(\mathrm{CO})_{2}\right]_{2}(21.2 \mathrm{mg}$ $54.5 \mu \mathrm{mol})$ and $\mathbf{1}(158.5 \mathrm{mg}, 110.1 \mu \mathrm{mol})$ were stirred in $8 \mathrm{~mL}$ of $\mathrm{CH}_{2} \mathrm{Cl}_{2}$ for $6 \mathrm{~h}$, giving a light yellow solution. After removal of the solvent in vacuo, $\mathbf{8}$ was obtained as a microcrystalline solid. Single crystals suitable for $\mathrm{X}$-ray analysis were obtained by slow diffusion of $\mathrm{CH}_{3} \mathrm{CN}$ into a $\mathrm{CH}_{2} \mathrm{Cl}_{2}$ solution. ${ }^{1} \mathrm{H} \mathrm{NMR}$ $\left(\mathrm{CDCl}_{3}\right): \delta 7.97(\mathrm{~m}, 2 \mathrm{H}), 7.81(\mathrm{~d}, 4 \mathrm{H}), 7.40(\mathrm{~m}, 10 \mathrm{H}), 7.06(\mathrm{q}$, $\left.4 \mathrm{H},{ }^{1} \mathrm{~J}=7.2 \mathrm{~Hz}\right), 2.00-1.18\left(\mathrm{br} m, c_{-} \mathrm{C}_{5} \mathrm{H}_{9}\right), 1.15\left(\mathrm{~m}, \mathrm{c}-\mathrm{C}_{5} \mathrm{H}_{9}\right)$, $0.94\left(\mathrm{br} \mathrm{m}, \mathrm{c}^{-} \mathrm{C}_{5} \mathrm{H}_{9}\right), 0.35\left(\mathrm{~s}, \mathrm{SiMePh}_{2}\right) .{ }^{31} \mathrm{P} \mathrm{NMR}\left(\mathrm{CDCl}_{3}\right): \delta$ $110.1\left(\mathrm{~d}, \mathrm{~J}_{\mathrm{Rh}-\mathrm{P}}=145 \mathrm{~Hz}\right) .{ }^{29} \mathrm{Si} \mathrm{NMR}\left(\mathrm{CDCl}_{3}\right): \delta-11.46$, $-65.60,-65.76,-66.47,-66.53,67.80$. FTIR (ATR mode, solid, $\left.\mathrm{cm}^{-1}\right)$ : $v 1995(\mathrm{Rh}(\mathrm{CO}))$. Anal. Calcd for $\mathrm{C}_{73} \mathrm{ClH}_{96} \mathrm{O}_{13} \mathrm{P}_{2} \mathrm{RhSi}_{8}$ : C, 54.58; H, 6.02. Found: C, 54.08; H, 5.73.

Computational Methods. For all the presented calculations, the Gaussian98 series of computer programs have been used. 43

Density Functional Methods. Standard computational methods based on the density functional theory have been employed. ${ }^{44}$ The functional used is the three-parameter exchange functional of Becke $\mathrm{e}^{45}$ together with the correlation functional of Lee, Yang, and Parr (B SLYP). ${ }^{46} \mathrm{~F}$ or P, C, O, Si, and $\mathrm{H}$ the basis set used is the Pople style basis set $6-31 \mathrm{G}^{47}$ with diffuse $(+) s$ and $p$ functions added on the heavy atoms ${ }^{48}$ and polarization function ${ }^{49}(d, p)$, adding one $d$ function on the heavy atoms and one $p$ function on the hydrogens (6-31+G$(d, p))$.

The geometries of all the model compounds have been fully optimized using analytical gradient techniques at the B3LYP level of theory previously cited. No symmetry constraints have been introduced. The optimized stationary points have been confirmed through a harmonic vibrational analysis (B3LYP level), using analytical or numerical differentiation of the obtained analytical energy first derivative.

Crystal Structure Determination of 5. Intensity data were collected using graphite-monochromated Mo K $\alpha$ radiation, on a Nonius KappaCCD diffractometer. A correction for absorption was considered unnecessary. The structure was

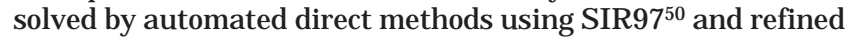

on $\mathrm{F}^{2}$ using SHELXL97. ${ }^{51} \mathrm{~F}$ our of the seven cyclopentyl rings and one of the six phenyl rings of the ligand are disordered over two conformations and refined with a disorder model. The crystal structure contains voids (495.7 $\AA$ \% $/$ unit cell) filled with disordered solvent molecules (dichloromethane/acetonitrile). Their contribution to the structure factors was ascertained using PLATON/SQUEEZE (158 e/unit cell).52 All non-hydrogen atoms were refined with anisotropic displacement parameters. All hydrogen atoms were constrained to idealized geometries and allowed to ride on their carrier atoms with an isotropic displacement parameter related to the equivalent displacement parameter of their carrier atoms. Structure validation and molecular graphics preparation were performed with the PLATON package. ${ }^{52}$ Crystal data are given in Table 7.

Crystal Structure Determination of 6. Intensity data were collected using graphite-monochromated Mo K $\alpha$ radiation, on a Nonius KappaCCD diffractometer. An empirical absorption correction was applied using PLATON/DELABS

(43) Frisch, M. J .; Trucks, G. W.; Schlegel, H. B.; Scuseria, G. E.; Robb, M. A.; Cheeseman, J . R.; Zakrzewski, V. G.; Montgomery, J . A., J r.; Stratmann, R. E.; Burant, J . C.; Dapprich, S.; Millam, J. M.; Daniels, A. D.; Kudin, K. N.; Strain, M. C.; Farkas, O.; Tomasi, J .; Barone, V.; Cossi, M.; Cammi, R.; Mennucci, B.; Pomelli, C.; Adamo, C.; Clifford, S.; Ochterski, J .; Petersson, G. A.; Ayala, P. Y.; Cui, Q.; Morokuma, K.; Malick, D. K.; Rabuck, A. D.; Raghavachari, K. Foresman, J. B.; Cioslowski, J .; Ortiz, J . V.; Stefanov, B. B.; Liu, G.; Liashenko, A.; Piskorz, P.; Komaromi, I.; Gomperts, R.; Martin, R. L.; Fox, D. J .; Keith, T.; Al-Laham, M. A.; Peng, C. Y.; Nanayakkara, A.; Gonzalez, C.; Challacombe, M.; Gill, P. M. W.; J ohnson, B. G.; Chen, W.; Wong, M. W.; Andres, J. L.; Head-Gordon, M.; Replogle, E. S.; Pople, J . A. Gaussian 98, revision A.3; Gaussian, Inc.: Pittsburgh, PA, 1998.

(44) Parr, R. G.; Yang, W. In Density Functional Theory of Atoms and Molecules; Parr, R. G., Yang, W., Eds.; Oxford Science Publications: Oxford, U.K., 1989.

(45) Becke, A. D. J . Chem. Phys. 1993, 95, 5648.

(46) Lee, C.; Yang, W.; Parr, R. G. Phys. Rev. B 1988, 37, 785.

(47) Hehre, W. J .; Ditchfield, R.; Pople, J . A. J . Chem. Phys. 1972, 56, 2257.

(48) Frisch, M. J .; Pople, J . A.; Binkley, J . S. J . Chem. Phys. 1984, 80,3265

(49) Krishnan, R.; Binkley, J . S.; Seeger, R.; Pople, J . A. J . Chem. Phys. 1980, 72, 650

(50) Altomare, A.; Burla, M. C.; Camalli, M.; Cascarano, G. L.; Giacovazzo, C.; Guagliardi, A.; Moliterni, A. G. G.; Polidori, G.; Spagna, R.; J . Appl. Crystallogr. 1999, 32, 115.

(51) Sheldrick, G. M. SHELXL 97; University of Göttingen, Göttingen, Germany, 1997.

(52) Spek, A. L. PLATON, A Multipurpose Crystallographic Tool; Utrecht University, Utrecht, The Netherlands, 2003. 
(transmission 0.550-0.894). ${ }^{52}$ Compound 6 is isomorphous with its $\mathrm{Pd}$ analogue 5; the atomic positions of the latter compound were used as the initial model for $\mathbf{6}$. The structure was refined on $\mathrm{F}^{2}$ using SHELXL97.51 Four of the seven cyclopentyl rings and one of the six phenyl rings of the silsesquioxane-bis $\left(\mathrm{PPh}_{2}\right)$ ligand are disordered over two conformations and were refined with a disorder model. The crystal structure contains voids (404.2 $\AA^{3} /$ unit cell) filled with disordered solvent molecules (dichloromethane/acetonitrile). Their contribution to the structure factors was ascertained using PLATON/SQUEEZE (122 e/unit cell).52 All non-hydrogen atoms were refined with anisotropic displacement parameters. All hydrogen atoms were constrained to idealized geometries and allowed to ride on their carrier atoms with an isotropic displacement parameter related to the equivalent displacement parameter of their carrier atoms. Structure validation and molecular graphics preparation were performed with the PLATON package. ${ }^{52}$ Crystal data are given in Table 7.

Crystal Structure Determination of 7. The data for $\mathbf{7}$ were collected on a Bruker SMART APEX CCD diffractometer. Data integration and global cell refinement were performed with the program SAINT. Intensity data were corrected for Lorentz and polarization effects. The structure was solved by Patterson methods, and extension of the model was accomplished by direct methods applied to difference structure factors using the program DIRDIF. ${ }^{53}$ The positional and anisotropic displacement parameters for the non-hydrogen atoms were refined. Refinement was frustrated by a disorder problem: from the solution, it was clear that one of the dichloromethane solvent molecules was highly disordered and probably partially occupied. The BYPASS procedure ${ }^{54}$ was used to take into account the electron density in the potential solvent area, which resulted in an electron count of 31, within a volume of $269 \AA^{3}$ in the unit cell. In addition, some disorder was observed in one of the cyclopentyl rings for the positions of C70 and C71. A disorder model with two conformations was refined: the sof of the major fraction of the component of the disorder model was refined to a value of $0.759(5)$. The hydrogen atoms were included in the final refinement riding on the $\mathrm{C}$ atom as appropriate with $\mathrm{U}_{\text {iso }}=\mathrm{cU}_{\text {equiv. }}$. Final refinement on $\mathrm{F}^{2}$ carried out by full-matrix least-squares techniques converged at $R_{w}\left(F^{2}\right)=0.1057$ for 21387 reflections and $R(F)=$ 0.0375 for 18554 reflections with $F_{\circ} \geq 4.0 \sigma\left(F_{\circ}\right)$ and 975 parameters. Crystal data are given in Table 7.

Crystal Structure Determination of $\mathbf{8}$. The data for $\mathbf{8}$ were collected on a Bruker SMART APEX CCD diffractometer. Data integration and global cell refinement were performed with the program SAINT. Intensity data were corrected for Lorentz and polarization effects. The structure was solved by

(53) Beurskens, P. T.; Beurskens, G.; de Gelder, R.; Garçía-Granda, S.; Gould, R. O.; Israël, R.; Smits, J . M. M. The DIRDIF-99 Program System; University of Nijmegen, Nijmegen, The Netherlands, 1999.

(54) van der Sluis, P.; Spek, A. L. Acta Crystallogr. 1990, A46, 194.
Patterson methods, and extension of the model was accomplished by direct methods applied to difference structure factors using the program DIRDIF. ${ }^{53}$ The positional and anisotropic displacement parameters for the non-hydrogen atoms were refined. Refinement was frustrated by a disorder problem: some atoms showed unrealistic displacement parameters when allowed to vary anisotropically, suggesting dynamic disorder (dynamic means that the smeared electron density is due to fluctuations of the atomic positions within each unit cell). The smeared electron densities for $\mathrm{C} 7-\mathrm{C} 12$ and C55-C59 have been described by two site occupancy factors, respectively, with separately refined displacement parameters. A disorder model with bond restraints was used in the refinement. The sof of the major fraction of the component of the disorder model was refined to values of $0.512-$ (5) and $0.707(5)$, respectively. The $C 7$ positions converged to nonpositive-definite displacement parameters when allowed to vary anisotropically; thus, ultimately this was returned to an isotropic displacement parameter. The C73-O13 distance converged to an unrealistically short distance of $0.99 \AA$. This short "distance" might suggest a substitutional disorder with the $\mathrm{Cl}$ position. Therefore, ultimately, the distribution of the substitution was refined. The major fraction was refined to a value of $0.880(5)$. This "distance" of $\mathrm{C}-\mathrm{O}$ suggested a substitutional disorder with the $\mathrm{Cl}$ position. Thus, ultimately, the distribution of the substitution was refined. The major fraction was refined to a value of $0.879(5)$. The hydrogen atoms were included in the final refinement riding on the $\mathrm{C}$ atom as appropriate with $\mathrm{U}_{\text {iso }}=\mathrm{CU}_{\text {equiv. }}$ Final refinement on $\mathrm{F}^{2}$ carried out by full-matrix least-squares techniques converged at $R_{w}\left(F^{2}\right)=0.1111$ for 18032 reflections and $R(F)=0.0421$ for 14251 reflections with $\mathrm{F}_{\mathrm{o}} \geq 4.0 \sigma\left(\mathrm{F}_{\mathrm{o}}\right)$ and 970 parameters. Crystal data are given in Table 7.

Acknowledgment. This work was financially supported by the National Research School Combination for Catalysis (NRSCC) (J .I.v.d.V.) and Avantium Technologies (M.F.) and in part (A.M.M. and A.L.S.) by The Netherlands Foundation of Chemical Research (SON) with financial aid from The Netherlands Organization for Scientific Research (CW-NWO). The Erasmus Program of the European Union is thanked for a travel grant ( .A.). OMG is acknowl edged for a generous loan of various transition-metal complexes. Dr. Rafaël Sablong, Dr. Christian Müller, and Michiel Grutters, M.Sc., are kindly acknowledged for their respective contributions in scientific discussions.

Supporting Information Available: Tables and figures giving detailed information about the $\mathrm{X}$-ray crystal structure analyses of 5-8. This material is available free of charge via the Internet at http://pubs.acs.org.

OM030522Y 